\title{
Design of Physical Spaces in Medical Laboratories
}

\author{
Soroush Darafarin *,1 (D), Sajjadeh Movahedinia2 ${ }^{\text {iD }}$, Hossein Darafarin ${ }^{3}$ (D) Marjan R. Farzami ${ }^{4}$
}

1. Architect Designer, Gorgan Pathobiology Laboratory, Tehran, Iran

2. Pathology and Stem Cell Research Center, Department of Pathology, Afzalipour School of Medicine, Kerman University of Medical Sciences, Kerman, Iran

3. Gorgan Pathobiology Laboratory, Tehran, Iran

4. Reference Laboratory, Health Reference Laboratory (HRL), Ministry of Health and Medical Education, Tehran, Iran

\section{ABSTRACT}

Background and Aim: The system of architectural design, space and installation of facilities and equipment in the medical laboratory is based on a multifaceted structure. Considering these conditions increases the productivity and profitability to all the involved groups. The present study sought to understand and design of this structure.

Materials and Methods: This descriptive-analytical research was carried out studying the literature.

Results: According to the results, the adequate architectural design for a medical laboratory includes the following points: observing the separation of physical spaces, proximity of the spaces in the laboratory, the principle of flexibility in designing physical space and the ability to develop and expand the physical space, the space design and requirements to meet the mobility needs of the people with disabilities, desk designing for the disabled and the elderlies, observing the minimum standards of general space and total spaces, and the number of staff considering their safety.

Conclusion: The design of medical laboratories, considering the cases mentioned in this report, will lead to the construction of a place that will not only meet the needs of clients but also provide comfort and safety for the staff. Such a laboratory will be more profitable by increasing the productivity, which will ultimately lead to a comprehensive profit. The errors and mistakes in the design and execution of any of these cases can cause minor and major damages.

Keywords: Architectural design, Medical laboratory, Physical space, Physical space separation, Safety

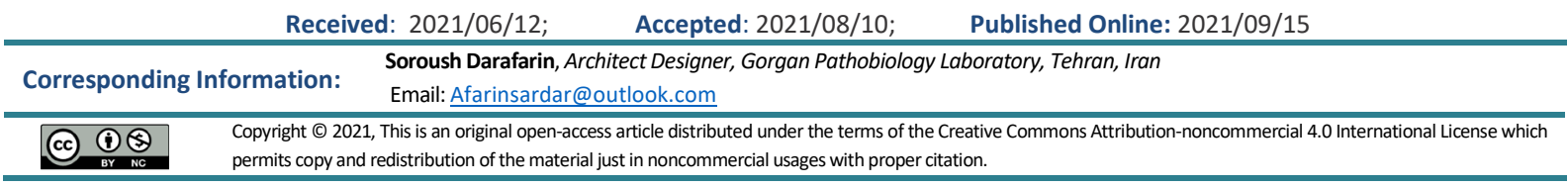

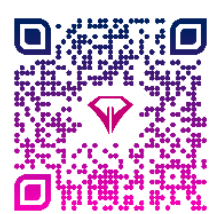

Use your device to scan and read the article online

Darafarin S, Movahedinia S, Darafarin H, R. Farzami M. Design of Physical Spaces in Medical Laboratories. Iran J Med Microbiol. 2021; 15 (5) :480-506

\section{Download citation: BibTeX | RIS | EndNote | Medlars | ProCite | Reference Manager | RefWorks |}

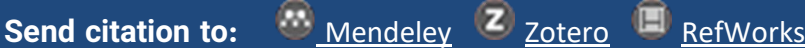

\section{Architectural Design in a Medical Laboratory}

Laboratories are made up of various structural dimensions from space, equipment and small number of staff to large laboratories including various spaces, specialized manpower, and various equipment. Accordingly, the design of laboratories should be formed based on the needs, facilities, manpower, equipment, and available space (1).

The laboratory design includes pre-design according to the user needs, situations and accesses according to the context, flexibility of the space for the future development, equipment, staff and various activities in unpredictable cases, safety and increase in the productivity including biosafety cabinets, fire protection and prevention systems, emergency shower, well-designed exits, proper ventilation and temperature control systems, and finally physical planning (1).

Observing the minimum conditions and standards necessary for the design and implementation of a medical laboratory will not only create a suitable 
space for the staff and clients, but also increase the productivity by optimizing the affairs. The shortcomings and mistakes in this context even minor can cause irreparable damages.

This study tries to examine the dimensions, requirements and standards in the field of medical laboratories design. The identifying damages and safety protocols as well as the risks involved in this case are not within the scope of this study.

\section{Research Method}

The methodology of this research was based on the descriptive and analytical method. In this research, the design of the space was demonstrated, by collecting the articles and reliable sources regarding the physical design of the laboratories. The collected sources were analyzed and cited.

\section{Components and Stages of Architectural Design in a Medical Laboratory}

\section{3-1- Pre-design}

One of the main stages of designing laboratories is pre-design. At this stage, the overall design is done with flexibility in the use of spaces and the possibility to move if necessary. The designer must also consider the factors such as adapting the laboratory environment to different people and devices. Compliance with the principle of flexibility in predicting the infrastructure of mechanical installations (type and capacity of units and access to the risers and so on) and electrical installations (system capacity and location of sockets) in order to allow for the intended displacements, resolves this problem well (Figure 1).

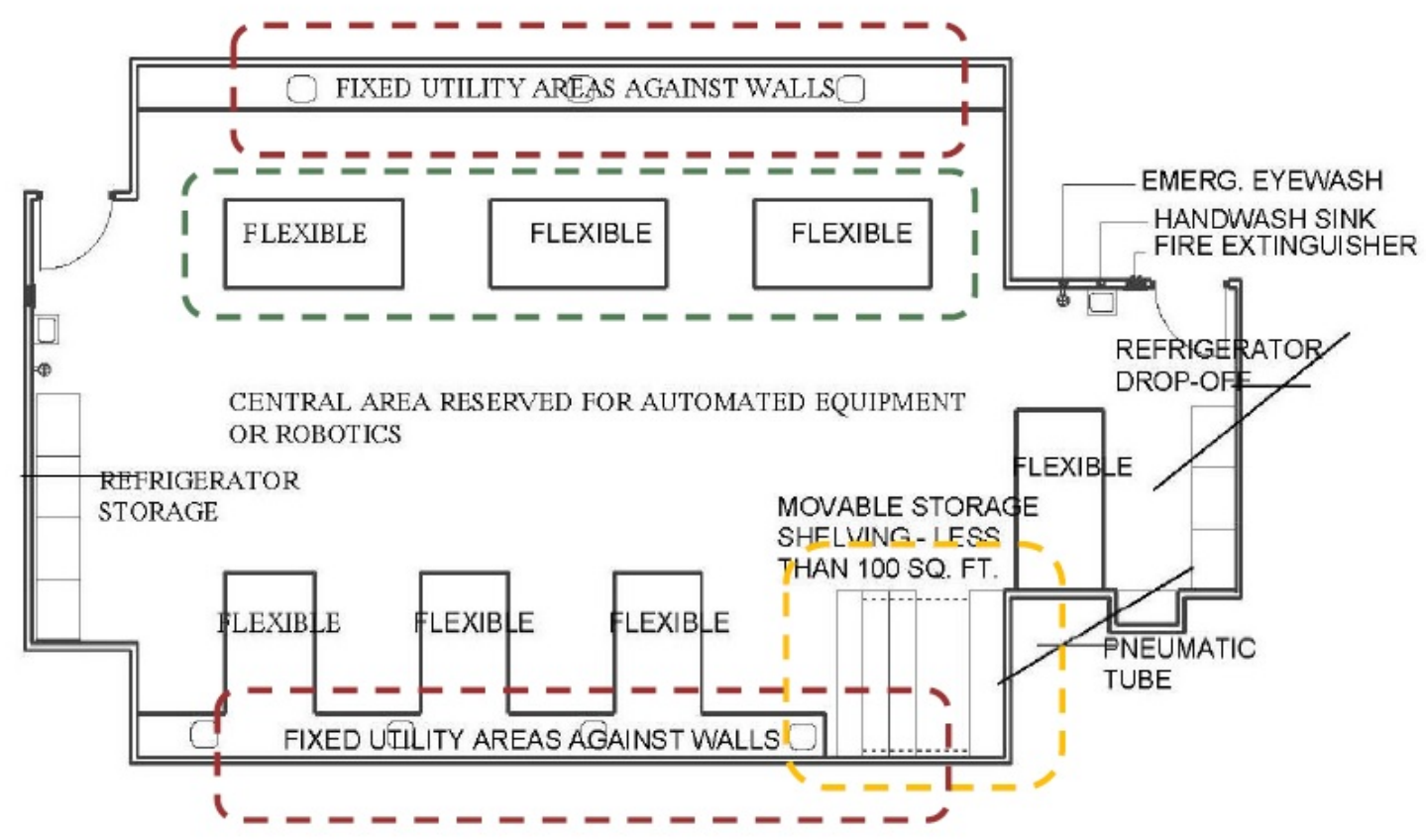

Figure 1. Schematic diagram of laboratory workspace for the mobile and flexible workstations (2).

\section{3-1-1- Space Design and Requirements}

\section{3-1-1-1- Proximity of Space}

The related technical section in a medical laboratory should be integrated and adjacent to each other or at least as close as possible, while some laboratory spaces should be separated from other sections. The following three conditions can be considered for the proximity of spaces in the laboratory:

\section{- Adjoining Spaces}

For adjoining spaces, technical sections such as biochemistry, hematology, immunology and serology can be mentioned.

\section{- Adjacent Spaces}

For adjacent spaces, the proximity of the reception space, sampling and sample separation can be mentioned.

\section{- Separated Spaces}

For separated spaces these sections can be mentioned: washing and sterilization spaces, refrigerated and non-refrigerated storages, server and central UPS rooms, dining and rest room, staff locker room and technical departments including microbiology, urology, mycology, parasitology, virology, molecular laboratory and others (3). 


\section{3-1-1-2- Requirements in Meeting the Mobility Needs of People with Disabilities}

Paying attention to the mobility needs of the disabled people in the city and building scale is one of the minimum standards of the developed countries, which in our country has not received much attention. This issue should be considered for the patients, clients and laboratory staff (3).

Among the points and requirements related to the mobility needs of the disabled people these items can be pointed. For example, the possibility of movement in all the main spaces of the laboratory, easy access considering the spaces dimensions, net width of the entrances and corridors and elevator cabs (with built- in handrails), installation of laboratory tables with the ability to height adjust for the people in wheelchairs, the use of laboratory hoods with the ability to use while sitting, adaptation of toilets, and designing a recall or audio pager system suitable for the people with hearing problems.

Obviously, the number of these facilities at the laboratory level should be determined in proportion to the number of staff and their daily admission. These cases should be designed in a way to allow people with disabilities to enter and exit easily in emergency situations (4). Figure 2 shows an example of a space design for the people in wheelchair (5).

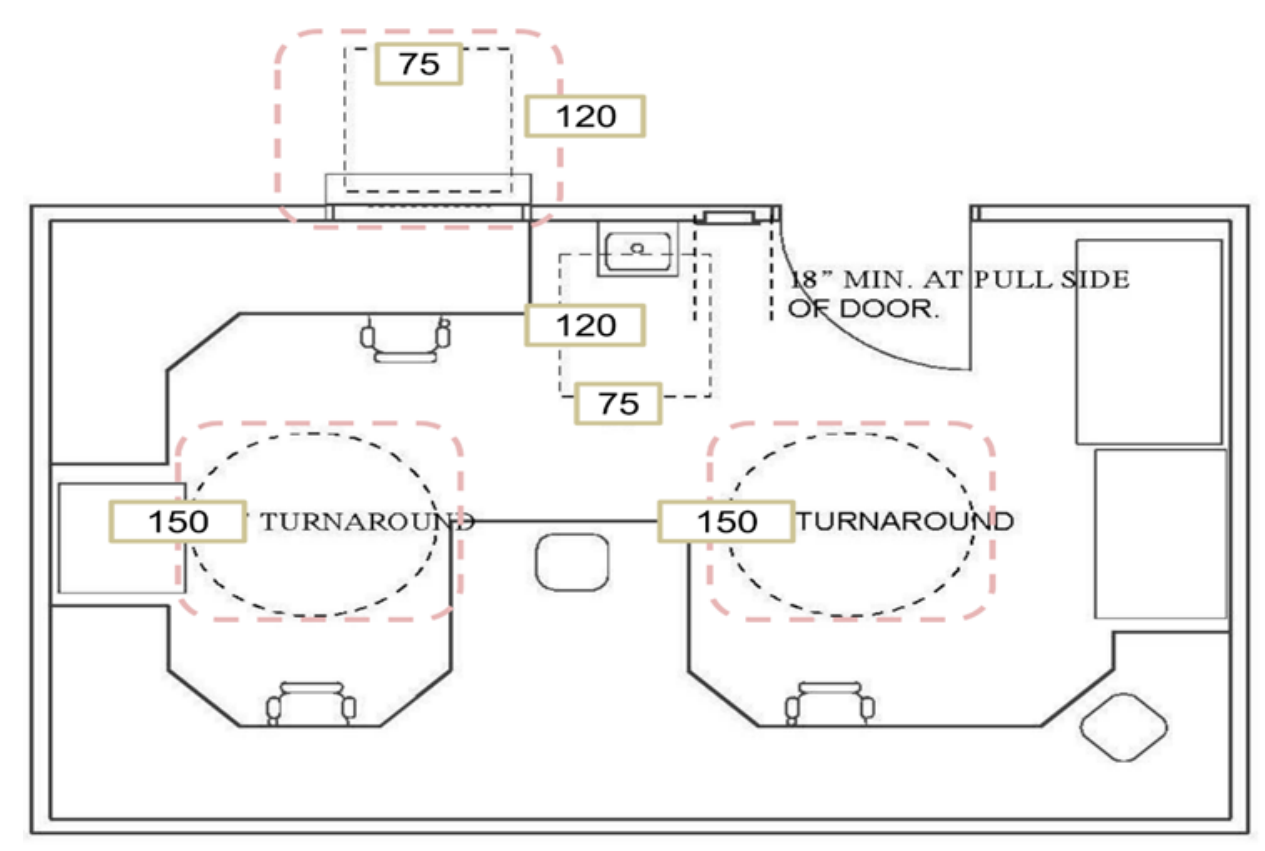

Figure 2. Minimum dimensions of desktop design for the disabled and elderlies (5).

\section{3-1-2- Quality of Medical Laboratory Space}

The most important factor in providing quality in a space depends on the appropriateness of the space by the user type. This proportion does not only include the quantity and size of the space, but a set of factors such as light, ventilation, electricity, water and sewage, the equipment arrangements, the type of steps and platforms, and safety levels all play roles in shaping the overall quality of a space. The existence of unnecessary columns, walls and partitions can reduce the quality of a space (6).

\section{3-2- Physical Planning}

\section{3-2-1- Physical Planning of Laboratory Spaces}

In the design process, after pre-design, the attention is paid to the physical planning of the space. In physical planning of laboratory spaces, the required area is determined by listing the required spaces, their user description and their communication system $(5,3)$.

\section{3-2-2- Quantity and Separation of Medical Laboratory Spaces}

Mostly, the minimum physical space that seems sufficient at the opening of a laboratory becomes inadequate and inefficient with the development and growing process of the laboratory and the definition of new experiments and equipment and also new technical departments and staff. Sometimes even to provide a little space needed, the narrow corridors of the laboratory are inevitably used for the technical applications. Sometimes, due to financial and economic constraints or lack of prediction and information about the expansion and development of laboratory activities in the future, the minimum space is considered for the initial space. In these cases, this 
space should be provided in a place where side spaces or the other floors should be available in its vicinity. With a detailed study and comprehensive information, the relative area needed to expand the space in the future should be considered (2).

At present, according to the regulations for the establishment and administration of medical laboratories, the minimum space that fits for the type of laboratory activity is $120 \mathrm{~m}^{2}$ for the clinical and descriptive pathology laboratories, $100 \mathrm{~m}^{2}$ for the clinical laboratories and $60 \mathrm{~m}_{2}$ for the single specialized laboratories (4). A suitable space should be provided for the work in the laboratory to ensure the quality, safety and efficiency of the services, and the health and safety of the staff, patients and clients. The suitability and suffice of the dedicated spaces should be evaluated and determined for the activities (4).
Insufficient work space or improper design of physical space can be potentially the source of many laboratory accidents and hazards and endanger the safety of staff, such as the physical contact of staff with each other during work (with the risk of contamination with infectious, chemical and hazardous substances), or the staff contact with equipment that could result in physical injury to the staff and damage to the equipment. Therefore, the design of a laboratory should include the design of the required sections, their area and their arrangements.

\section{3-2-3- Main Sections of Medical Laboratory}

Every medical laboratory needs different departments. These sections include the client lounge, reception and cashier, sampling section, blood bank, supervisor room, etc. Figure 3 depicts an ideal image of a medical laboratory parts.

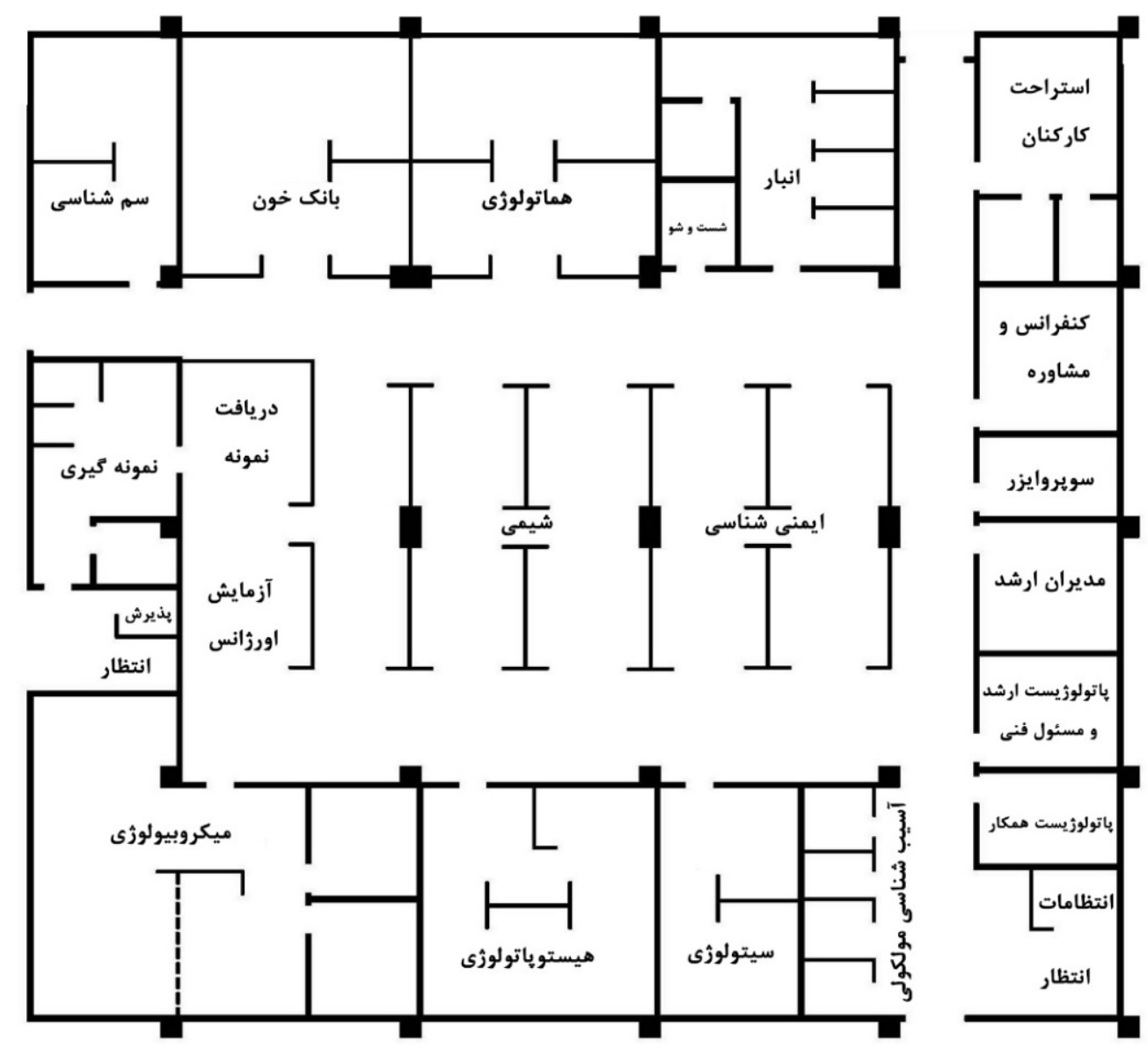

Figure 3. Schematic view of different laboratory spaces based on HMI index (2).

\section{3-2-4- Separation of Physical Space}

Separation and organization of physical space is the most controversial and important issue in the laboratory design that should be defined by considering the overall dimensions of the laboratory, the number of staff, the volume of technical operations, the type of experiments, and the size of equipment in each technical department (7).

Some spaces must be defined isolated from other laboratory spaces, including the microbiology, 
mycology, washing, and sterilization sections. In addition, office and sampling spaces should be separate from other spaces. The corridors between workspaces should be designed in such a way that the staff safety in the work space is maintained. The corridors should be wide if possible (8).
The minimum standard width of corridors and laboratory tables according to the laboratory design guide (GP18A2) is one and a half meters, which is shown in Figure 4 (8).
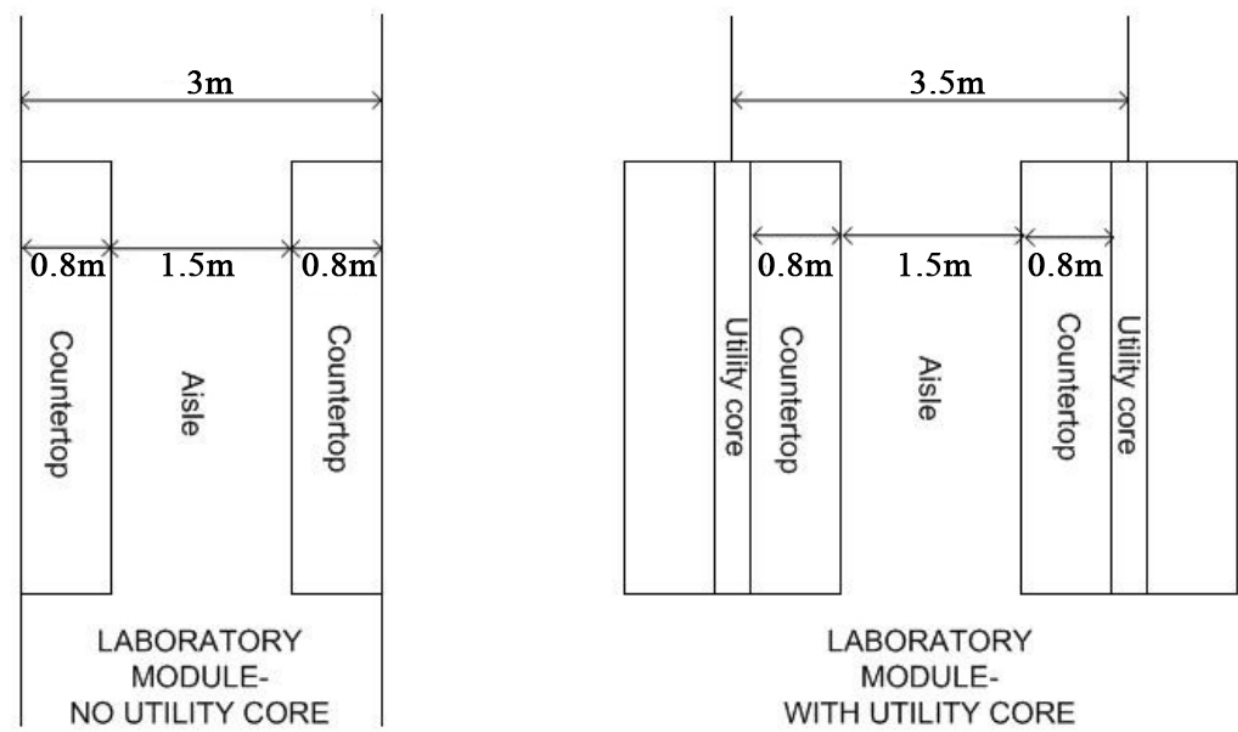

Figure 4. Minimum width of laboratory tables according to the laboratory design guide (6).

\section{3-2-5- Controlling and Monitoring the Laboratory Physical Space}

The design of physical space control systems is very necessary, in addition to the quantity and quality of the space. They include the design of audio and video systems and CCTV to control the number of active staff, movement and congestion of the patients and workflow time, the workflow of samples in workspace especially emergency samples, staff entry and exit, and also internet control from remote distance.

\section{3-2-6- Add or Remove Physical Space in the Laboratory}

Ideally, as the need for the space in the laboratory may increase or decrease, there should be possibility to expand or limit the physical space of the laboratory. In order to develop the space, it should be anticipated that potential lateral spaces of the laboratory will be available and usable (ability to buy or rent).

\section{3-2-7- Movement in the Medical Laboratory Physical Space}

Assessing the movement of staff and patients and clinical samples in the physical space is better to be drawn in a map and diagram and movement restrictions for each group to be specified; such as restricting the movement of patients to the technical spaces and restricting the movement of staff in specific spaces (for example, unskilled staff movement in the mycobacteriology or specialized microbiology or molecular department will not have any other outcome except for the contamination of the patients samples and the occurrence of false positive results and contamination of the staff). To draw this diagram, it is suggested to first magnify the laboratory spaces (in the map) and conduct the necessary analysis to design the spaces, including location, entrance of the workstations, equipment location and other items. The real map can be drawn after simulating this map (1).

\section{3-2-8- Sample Transfer System Design using Compressed air (Pneumatic System)}

The design of the sample transfer system using the compressed air has been considered in the developed countries. By designing this system in hospitals, laboratory samples can be easily transferred from the clinical wards of the hospital to the sample isolation unit and from the isolation unit to the technical wards. In independent central laboratories, samples will also be transferred from the sampling unit to the isolation and technical departments. In general, the advantages of this method include quick and easy access, reduction of traffic between different departments, cost reduction and sample safe transfer. 


\section{3-2-9- Location and Position of the Equipment in the Physical Space}

In the list of defined equipment in each physical space, except for the exact position and location of each piece of the equipment, the following items must be precisely defined and recorded (9):

- Dimensions of the equipment or device (length, width and exact height of the device) along with the minimum lateral space required for each equipment (distance from the wall and sides)

- Definition of the dimensions of the necessary peripherals for each device such as monitor, printer and UPS (preferably these peripherals should be placed in the space on the wall or behind the cabinet to provide more space for the work area)

- Definition of the power sources (required voltage and current for the device) and water and sewage system of the device

- Definition of the way to access the back and side spaces of the device during the service of large and bulky equipment (for example, it is better to place large and bulky equipment on a separate wheeled table so that, the service person can easily access the side and back spaces of the device with the least displacement and the least energy consumption).

- Prohibition of proximity of some equipment (for example, prohibition of proximity of centrifuge and microhematocrit with the cell counter, etc.)

- No proximity of the heat-sensitive equipment to the laboratory heating systems (especially ELISA desk).

- Keeping a minimum distance of $20 \mathrm{~cm}$ for the refrigerator to the wall for the heat exchange

- Suitable location for the equipment that generates high heat (a place with air circulation capability to prevent heat retention and damage to the equipment) and proximity of these equipment to the standard cooling systems

\section{3-2-10- Laboratory Furniture Design}

The laboratory furniture should have smooth and non-porous surfaces to resist the absorption of liquids and the severe effects of disinfectants. The furniture should not be positioned in such a way that makes cleaning the spilled liquids or performing routine tasks difficult. For example, placing a Class II biosafety cabinet in a confined concave space may not allow the biosafety cabinet certification to verify the cabinet panels upon re-inspection. These resources are applied specifically to the laboratories containing biological and radioactive materials (11).
Many common materials in the laboratory are chemical solvents such as formaldehyde, phenol, and ethanol, which are considered corrosive substances. The laboratory cabinets and benches must be resistant to the chemical reactions of these materials. Wooden bench covers are not suitable for this purpose because a wooden surface can absorb the liquids. Also, wood burns quickly in the event of a fire. Fiberglass is also unsuitable because it can be damaged by the use of strong disinfectants. Fiberglass also releases toxic fumes when burned (12). One of the factors that is suitable for the laboratory, is the use of sufficient natural or artificial light to ensure sufficient visibility for operational safety (13).

\section{3-2-11- Physical Space Required by the Medical} Laboratory Staff

The staff are one of the main and important elements of any medical laboratory. Thus, proper design of work space and their movement in the lab environment and the level of their safety in this space will be particularly effective in the staff satisfaction and final quality and overall performance of the laboratory.

The calculation of the total (technical) working space of the medical laboratory (TNS: Total Net Space) is obtained from the following equations:

$$
\begin{aligned}
& \text { TNS }=B W S+F M I \\
& B W S=[(A E+C W S) \times(C D+A W)]
\end{aligned}
$$

The abbreviation of the different physical spaces of the medical laboratory used in this formula is given in Table 1.

3-3- Safety, Increased Productivity and Necessary Equipment

\section{3-3-1- Biosafety Laboratories and Their Requirements Design}

Classification is based on the biosafety levels to provide information on how to protect staff and the laboratory environment against laboratory contaminations in order to achieve acceptable standards and guidelines. This information is also used to protect the health of laboratory processes by controlling the spread of various contaminants. In fact, the main purpose of the biosafety discussions in laboratories is that no experiment is more important than the safety. Therefore, it is necessary to plan and control bio-contaminations to protect against laboratory infections and control the spread of contaminants in laboratories that use contaminated and hazardous materials. Obviously, determining the type of laboratory in terms of biosafety levels can affect the way the laboratory is planned and designed. 
Table 1. The abbreviation of the different physical spaces of the medical laboratory (8)

\begin{tabular}{ll}
\hline TNS: Total Net Space & Total technical (working) space required for the laboratory \\
\hline BWS: Bench Work Space & Work space of laboratory platforms and tables \\
\hline FMI : Floor Mounted Items & Items attached to the laboratory floor (either fixed or glued) \\
AE : Analysis Equipments & Laboratory equipment space \\
\hline CWS : Clear Working Space & Clean space (without accessories) of laboratory \\
CD : Counter Depth & Depth (height) of counters \\
AW : Aisle Width & Side spaces (corridors) \\
\hline
\end{tabular}

In other words, biosafety is a widespread issue. Biosafety agents include personal protective equipment (PPE), four levels of biosafety cabinets, disinfectants, diagnostic methods including identification, evaluation and control of a wide range of microorganisms and environmental hazards, pathogens, viral agents, fungal agents, common human-animal agents, protozoa, and gene transfer vectors and biorisk management including regulations and guidelines for the risk assessment covering pathogenic microorganisms, allergens, toxins, aerobics, occupational medicine, and biological safety (14).

According to the definition of the World Health Organization (WHO), laboratory biosafety refers to the application of restrictive principles, technologies and methods to prevent the unintentional release of pathogens and toxins into the environment. The laboratory biosafety is applied to the set of security measures and methods used by the staff and organization to prevent the loss, theft, misuse, diversion or intentional release of pathogens and toxic substances. In the case of laboratory biosafety, in addition to physical protection, measures such as personnel management, material control and auditing, information protection, and transportation security should also be considered. Considering the above concepts, the architects and designers of the health centers should pay attention to these points in designing laboratories or hospitals (15).

\section{3-3-1-1- Biosafety Laboratory Level 1 and Its Requirements}

The level 1 laboratory is suitable for working with microorganisms with low risk level and laboratory personnel are adequately protected in accordance with the laboratory standards. The organisms tested in these types of laboratories do not cause disease in healthy people, and laboratory processes may be performed outdoors (outside the hood). Ventilation of this laboratory can be provided naturally.

Level 1 biosafety represents laboratories that have a basic level of safety and are based on the use of standard methods in disinfection. These laboratories are usually at the lowest level of biosafety, and precautions including regular hand washing and the use of protective equipment such as gloves, a separate wash sink, and appropriate disinfectants to disinfect surfaces and hands are necessary. The media containing microbial culture and residues should also be autoclaved (15).

3-3-1-2- Biosafety Laboratory Level 2 and Its Requirements

The level 2 laboratory is suitable for working with materials containing microorganisms that are associated with human diseases and have the ability to infect by ingestion and exposure to mucous membranes and are present in the environment. Using appropriate microbiological methods, the experiments can be performed out of hood. However, if there is a risk of airborne particles, a biosafety hood should be used.

These laboratories include the health service laboratories, and diagnostic, research, and training laboratories. In these types of laboratories, a wide range of microorganisms with moderate risk are worked that exist in the community and have different pathogenicities with low risk.

In level 2 laboratories, if aerosols (particulates in the air) are slightly formed during laboratory processes, in other words, if the risks of laboratory processes are low, they can be performed on benches without protection, but if these processes produce large amounts of aerosols and increase the risk of contact with these agents, biosafety hoods should be used.

\section{3-3-1-3- Biosafety Laboratory Level 3 and Its} Requirements

The level 3 laboratory is suitable for working on native or non-native pathogenic microorganisms that have the potential to be transmitted by the air and are dangerous to inhale or cause deadly disease. Pathogenic microorganisms in this group include MERS-COV, SARS-CoV-1, SARS-COV-2 and similar organisms (15).

Given the potential dangers of these pathogens, there are criteria for setting up a laboratory that manages the work and has the facilities to reduce the risk of microorganisms for human and environment. 
At this level, laboratory experiments are performed in a confined and controlled space (4). These laboratories include specialized diagnostic and research laboratories. Level 3 biosafety represents laboratories that require the use of biosafety cabinets or hoods in accordance with the international standards and secondary protections such as negative air pressure systems.

This level of laboratory in terms of laboratory operations includes all the requirements of level 2 in addition to the special clothing and coverings as well as controlled access (entry and exit restrictions) as well as directional airflow. In terms of safety equipment, most processes are performed in biosecurity hoods. A schematic view of a level 3 biosafety laboratory including the workspace, air, water and materials circulation, protective equipment, and entry and exit of individuals is shown in Figure 5 (16).

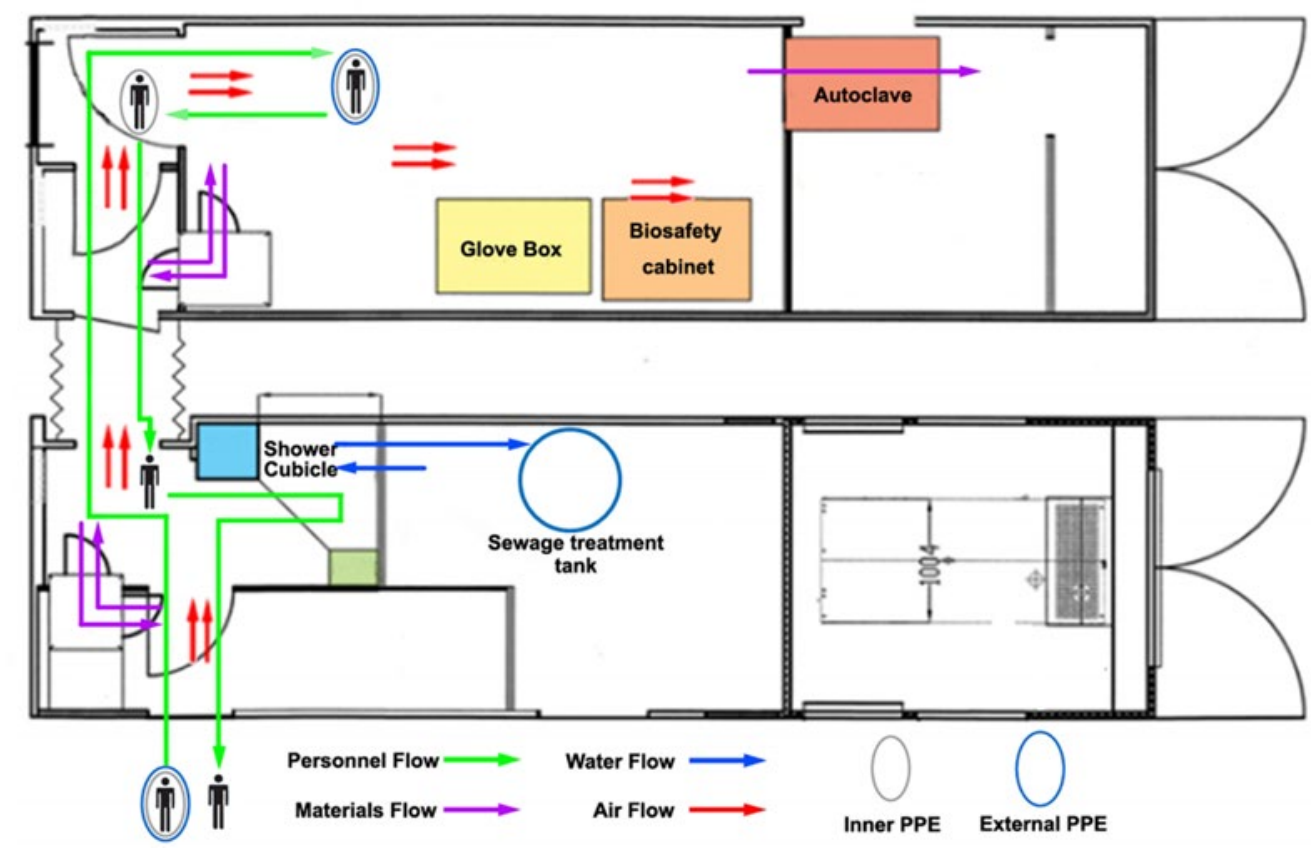

Figure 5. Schematic view of the hood location and air, water and materials circulation and the entry and exit of staff in the level 3 biosafety laboratory (12).

\section{3-3-1-4- Biosafety Laboratory Level 4 and Its Requirements}

The level 4 laboratory is suitable to conduct dangerous experiments with life-threatening microorganisms that spread rapidly through aerosols in the community. In general, the laboratories where the virus is cultured are level 4 , and this level of laboratory requires special requirements that must be considered in a separate building. In terms of the type of laboratory, it includes diagnostic units that are designed to detect dangerous pathogens (culture of microorganisms). These laboratories work with microorganisms that are transmitted through respiration and there is currently no suitable vaccine or treatment for them (4).

Dangerous and life-threatening pathogenic microorganisms of this group include viral hemorrhagic fever such as Marburg virus, Ebola virus, Lassa virus, Crimean Congo hemorrhagic fever and similar cases (4).
Level 4 biosafety represents laboratories that are considered very limited in terms of biosafety level and their building is located in a completely isolated area. The use of negative pressure system, shower and air lock are mandatory and are of great importance and sensitivity.

In terms of laboratory operations, it includes level 3 requirements along with air locking system at the entrance, shower at the exit, as well as special management for the proper waste disposal.

In terms of safety equipment, it consists of the use of Class 3 biosafety hood or positive pressure clothing with Class 2 biosafety hood, as well as a two-door autoclave (located between the walls) to remove material and filtered air (1). A schematic view of the four levels of biosafety and their equipment and facilities is shown in Figure 6 (17). 


\section{BSL1}

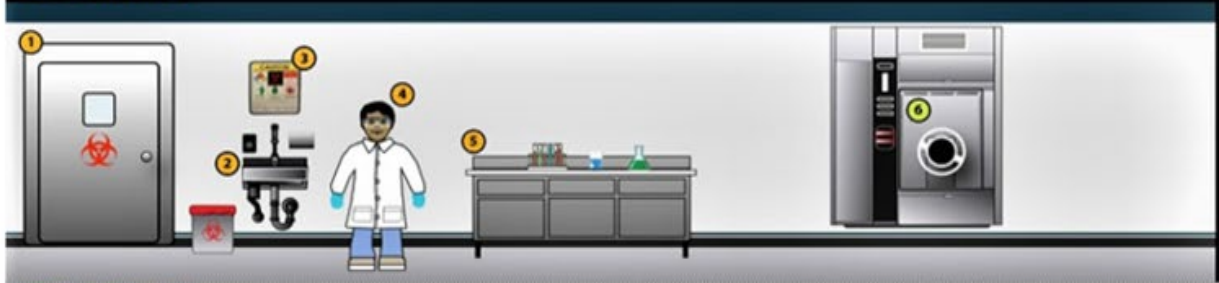

BSL2

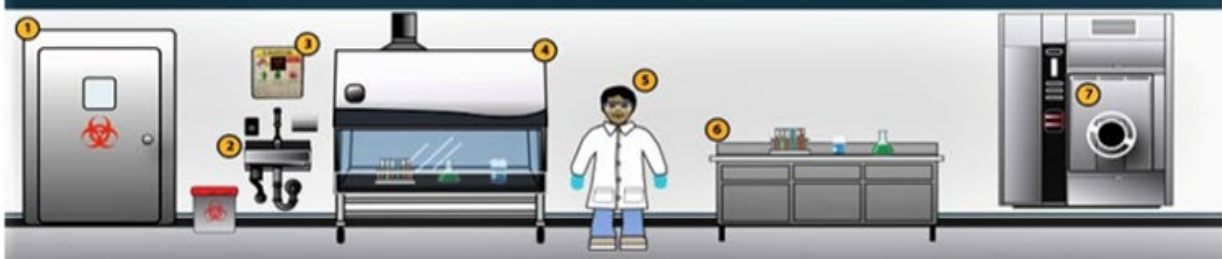

\section{BSL3 (WITH RISK-BASED ENHANCEMENTS)}

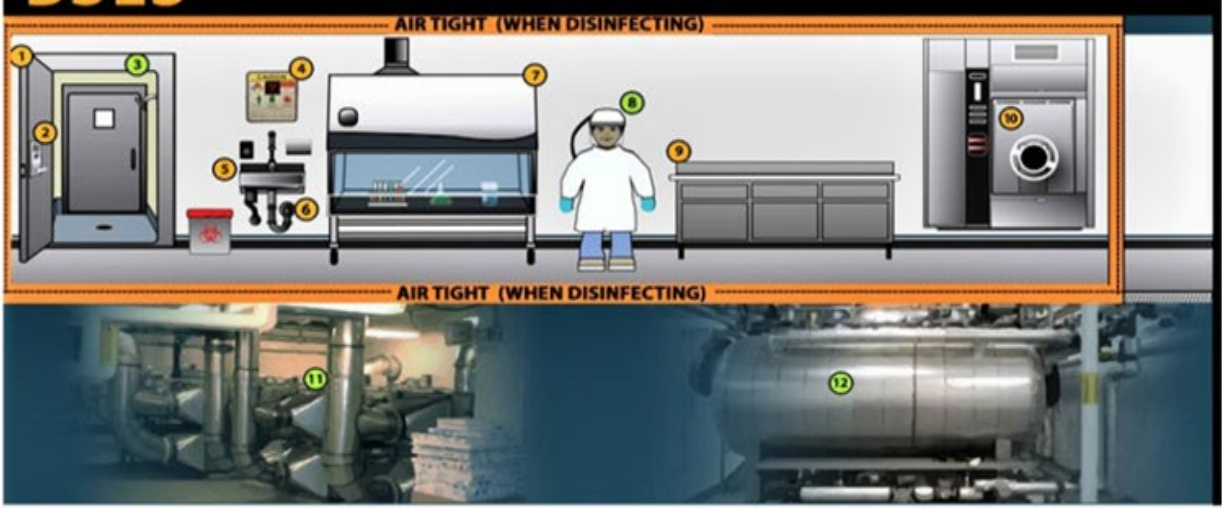

\section{BSL4}

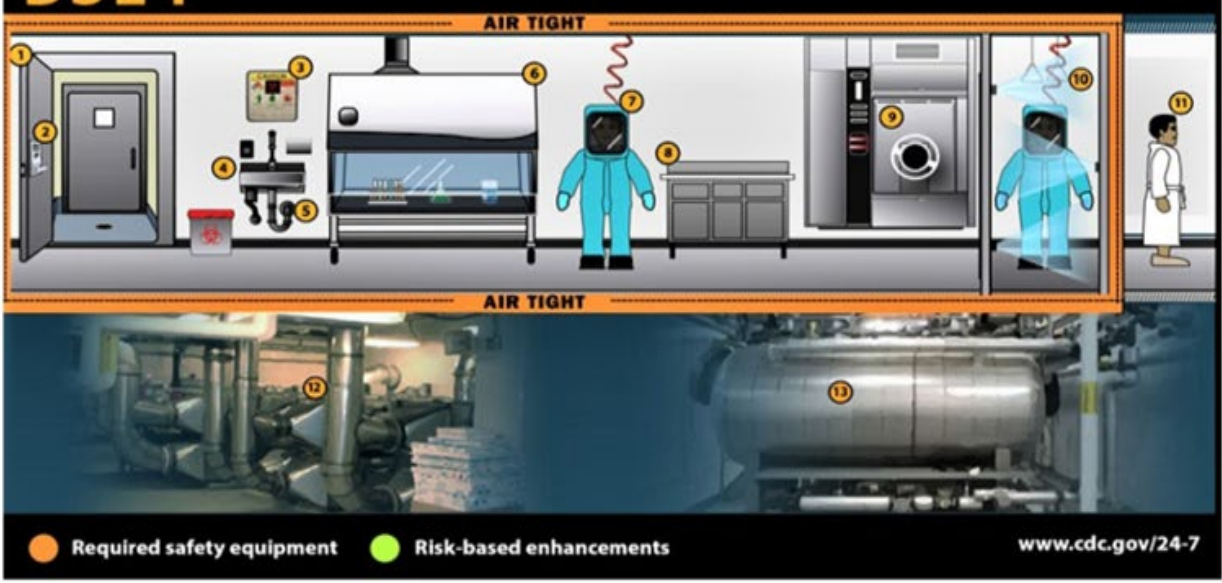

BSL1

1- Controlled Access

2- Hand Washing Sink

3- Sharp Hazards

Warning Policy

4- Personal Protective

Equipment

5- Laboratory Bench

6- Autoclave

BSL2

1- Controlled Access 2- Hand Washing Sink 3- Sharp Hazards Warning Policy 4- Physical

Containment Device

5- Personal Protective

Equipment

6- Laboratory Bench

7- Autoclave

BSL3

1- Self-Closing,

2- Controlled Access

3- Personal Shower ou

4- Sharp Hazards

Warning Policy

5- Hand Washing Sink

6- Sealed Penetrations

7-Physical

Containment Device

5- Powered Air

Purifying Respirator

9- Laboratory Bench

10- Autoclave

11- Exhaust HEPA

Filter

12-Effluent

Decontamination

System

BSL4

1- Self-Closing.

Double-Door Access

2- Controlled Access

3- Sharp Hazards

Warning Policy

4- Hand Washing Sink

5- Sealed Penetrations

6- Physical

Containment Device

7- Positlive Pressure

Protective Sult

8- Laboratory Bench

9- Autoclave

10- Chemical Shower

Out

11- Personal Shower

Out

12- Supply And

Exhaust HEPA Filters

13- Effluent

decontamination

system

Figure 6. A schematic view of the four levels of biosafety and their equipment and facilities is shown in Figure 6 (17).

\section{3-3-2- Proper Ventilation and Temperature Control Systems}

Mostly, air conditioning is perceived as cooling and heating, but it is important to know that it is not just about cooling or heating. Using air conditioning technology, the humidity, air flow rate, air pollution and air speed can be controlled. In other words, with the help of air conditioning, even airborne particles and air pollution can be eliminated. It removes excess moisture from the air and automatically maintains the amount of heat or cold required by the environment to provide comfort and relaxation for the people in the work and living environment. Air conditioning has not only general applications but also usage in sensitive areas such as gas disinfection rooms or special material storage environments (18). 


\section{3-3-3- Safety Regulations for Working with Recombinant DNA}

Recombinant DNA technology involves combining genetic material from different sources to create a genetically modified organism (GMO) that has never existed in nature. There are always concerns about undesirable and unpredictable properties of such organisms, especially if released suddenly in nature (20). The nature of the manipulated organism, the nature of the gene fragment transferred, the characteristics and conditions of storage, and working with the new organism are very important. A genetic order may give a new and unknown characteristic to the host organism. Therefore, observing the safety principles in all stages of genetic manipulation is necessary to minimize the negative effects of these studies (19).

\section{3-3-3-1-Working with Expression Systems to Produce Recombinant Proteins}

The expression systems include a host organism and a vector. The desired genes are cloned into the vector and transfected to the host. Escherichia coli is one of the most common bacteria used as an expression host. It is a non-pathogenic bacterium for the healthy humans and animals. After performing the genetic engineering manipulations, it is necessary to observe the safety principles (20).

If there is no accurate information about the input DNA fragment, it should be handled with extreme caution, like the condition when the genetic library is made from the genome of a pathogenic organism.

More caution should be exercised if the input gene product is toxic or has pharmacological and therapeutic effects (20).

\section{3-3-3-2-Working with Viral Vectors for Gene Transfer}

Viral vectors such as adenoviruses and other similar viruses are widely used to transfer genes to the cells. Such viruses lack some of the genes involved in reproduction and replication, and can replicate in the cells that make up this defect. Such viruses may regain their lost potential through recombination with other viruses or host cells. Therefore, it is necessary to always observe all the principles of safety working with complete viruses (21).

\section{3-3-4-Biosafety Cabinets (Hoods)}

The biologic safety cabinet (BSC) is a laboratory workspace that is used safely for the contaminated material or suspected pathogens. Biosafety hoods are designed as a reliable tool to protect the user, laboratory environment and work space against aerosols, contaminated discharges when working with infectious substances, and working with chemicals and radioactive materials.

Usually in different types of hoods (cabinets) biosafety is provided by the high efficiency filters against particles (High Efficiency Particle Air: HEPA) or filters resistant to fine particles (Ultra Low Particle Air: ULPA) at the system outlet (exhaust) or an air supply is used to trap aerosols. These filters are able to trap $97.99 \%$ of particles with a diameter of $0.3 \mu \mathrm{m}$ and 99.99\% of particles with larger diameters. Therefore, they create a safe environment in the laboratory.

Depending on the structure of these filters, the direction of airflow and the height of the window, different levels of protection of staff, product and work environment can be achieved.

The selection of an appropriate biosafety hood is based on the risk assessment of the types of biological organisms and other materials used.

\section{3-3-4-1-Types of Biosafety Cabinets and Their} Working Method

Biosafety hoods have been developed in three categories/classes 1, 2 and 3 based on the different needs of diagnostic and research centers.

Class 1 biosafety hoods have a filter located at the outlet that only protects the user from the chemicals and unpleasant odors. Most of these hoods have a HEPA filter, which returns the air to the environment after purifying. In Class 1 biosafety hoods, room air enters the interior part of the hood through the open front area and passes through the working surface and is discharged through the air outlet duct. Usually in these types of hoods, the room air enters the working surface at a speed of at least $38.0 \mathrm{~m} / \mathrm{s}$ and then enters the air outlet duct. Figure 7 shows a schematic of the operation of a Class 1 biosafety hood (22).

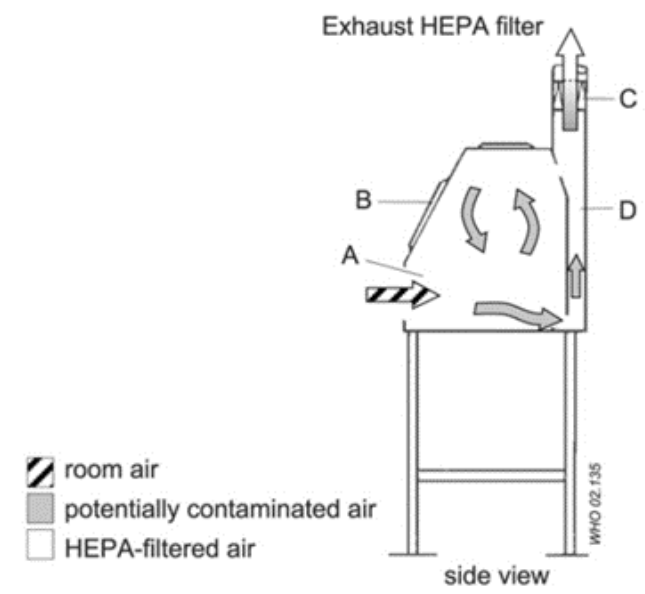

Figure 7. Schematic view of Class 1 biosafety cabinet operation (13) A: Front opening, B: Sash, C: Exhaust HEPA filter, D: Exhaust plenum. 


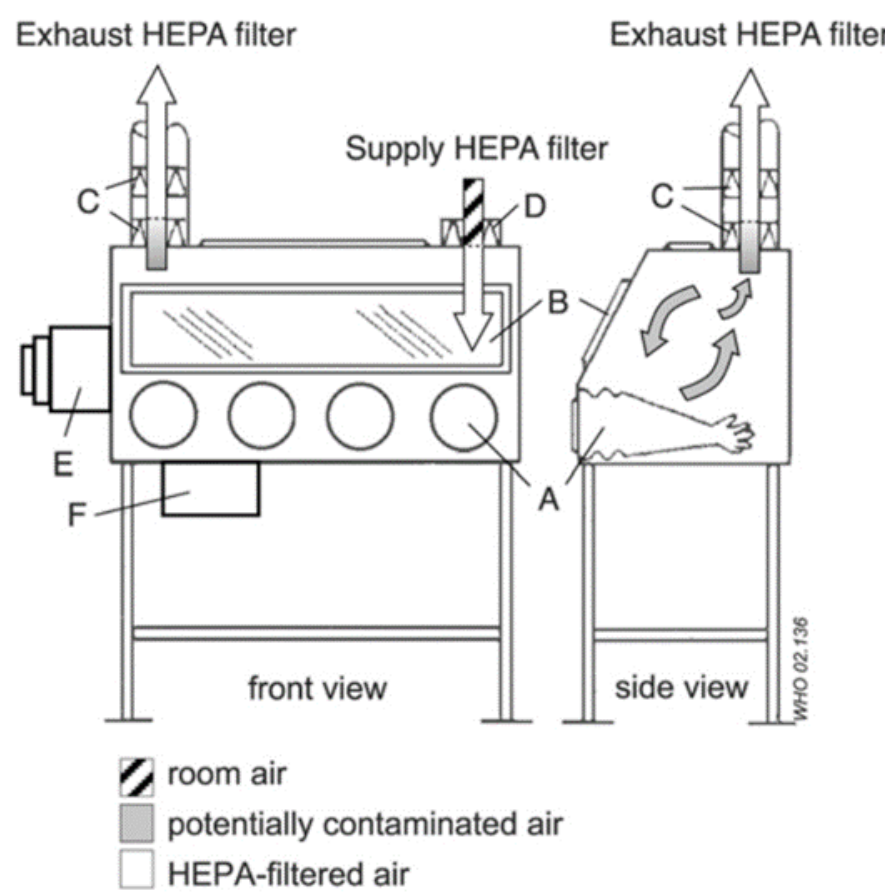

Figure 8. Schematic view of Class 3 biosafety cabinet operation (13).

Due to the need for cell and tissue culture to propagate viruses and so on, the passage of nonsterile air over the work surface causes contamination. Therefore, Class I biosafety hood is not applicable in these cases. For this purpose, to protect the work surface from the polluted room air, Class 2 biosafety hood was designed, in which sterile filtered air by HEPA filter flows on the work surface. Therefore, these hoods are used for cell and tissue cultures.

The Class 2 biosafety hood is the most common type of hood in a medical laboratory. These types of hoods protect the product in addition to the user. Basically, the rotation of indoor air is away from the user and does not return to him. When using this type of hood and working with hazardous chemicals, the hood with outlet duct (channel) must be used (1). Class 2 hoods can be used to work with the infectious agents in danger groups of two and three.

Class 2 hoods are produced in four different subcategories (types) of A1, A2, B1 and B2 based on the needs of the centers. Their difference is based on the air intake speed, the amount of air returning to the working surface, and the performance of the system determining the amount of exhaust air.

Class 3 biosafety hoods provide the highest level of employee protection and are suitable for working with danger group of four. All their pores are sealed and insulated to prevent any uncontrolled air flow to the hood. Access to the work surface is possible only through thick rubber gloves attached to the hood and insulated. In some types of these hoods, it is possible to use a two-door autoclave to decontaminate all contaminated materials and debris entering or leaving the hood. Class 3 biosafety hoods are suitable for work in levels 3 and 4 biosafety laboratories.

In Class 3 biosafety hoods, the air outside the hood first passes through the HEPA filter and then enters the hood. This purified air, after circulating inside, passes through the other two HEPA filters again and leaves the hood (1). A schematic of the operation of a Class 3 biosafety hood has been shown in Figure 8 (13).

\section{3-4- The Flexibility of Space for Future Development}

Advances in technology in medical laboratories and changes in requirements raise the need to anticipate changes in user space and future development in spaces. One of the things that can meet this need is the use of flexible partitioning systems with the ability to move and separate parts, which should be seriously considered in the design of the laboratory.

One of the problems, especially in hospital laboratories, is the surrounding of laboratory spaces with other parts of the hospital (23) that make it difficult to develop spaces. This problem should be considered in the initial design of hospital centers, so that, the desired environment in the development of hospital centers and consequently the laboratory will face fewer challenges. 


\section{Conclusion}

The design of medical laboratories, taking into account the issues mentioned in this article, will lead to the construction of a place that will not only meet the needs of clients but also provide comfort and safety for the staff. Such a laboratory will be more profitable by increasing the productivity, which will ultimately lead to a comprehensive profit. Errors in the design and execution of any of these items can cause minor and major damages which are beyond the scope of this discussion. As stated in this article, the design steps include pre-design, physical planning, safety and required equipment efficiency, and the flexibility of the space for future development, which should be considered in the design of the laboratory physical space. In addition, these steps themselves

\section{References}

1. Cooper EC. Laboratory design handbook: CRC Press; 2014. [DOI:10.1201/9781498710688]

2. Gebreyes M, Sisay A, Tegen D, Asnake A, Wolde M. Evaluation of Laboratory Performance, Associated Factors and Staff Awareness Towards Achieving Turnaround Time in Tertiary Hospitals, Ethiopia. Ethiopian Journal of Health Sciences. 2020;30(5).

[DOI:10.4314/ejhs.v30i5.17] [PMID] [PMCID]

3. Coleman CN, Hrdina C, Bader JL, Norwood A, Hayhurst R, Forsha J, et al. Medical response to a radiologic/nuclear event: integrated plan from the Office of the Assistant Secretary for Preparedness and Response, Department of Health and Human Services. Annals of Emergency Medicine. 2009;53(2):213-22. [DOI:10.1016/j.annemergmed.2007.12.021] [PMID]

4. Staff WHO, Organization WH. Laboratory Biosafety Manual: World Health Organization; 2004.

5. Blackler A, Brophy C, O'Reilly M, Chamorro-Koc $M$. Seating in aged care: Physical fit, independence and comfort. SAGE open medicine. 2018;6: 2050312117744925. [DOI:10.1177/2050312117744925] [PMID] [PMCID]

6. Lipscomb JA, El Ghaziri M. Workplace violence prevention: improving front-line health-care worker and patient safety. New solutions: a journal of environmental and occupational health policy. 2013;23(2):297-313.

[DOI:10.2190/NS.23.2.f] [PMID] include more detailed steps and requirements and standards that must be observed in the design of the physical space of the laboratory.

\section{Acknowledgment}

Not Applicable

\section{Funding}

This article is an independent study that was conducted without organizational financial support.

\section{Conflict of Interest}

The authors declared no conflict of interest.

7. Stephenson J, Association LDS. Building regulations explained: Routledge; 2003.

8. Mortland KK. Laboratory Design: Approved Guideline: CLSI; 2007.

9. Organization WH. Laboratory quality management system: handbook: World Health Organization; 2011.

10. Murat P, Naci C, Zehra Sule G, Cihan B, Hakan O. A New Formulation For The Fundamental Period Of Reinforced Concrete Planar Shear Walls. 2011.

11. Rice C. Radiation Safety Practices of NZ Veterinary Nurses. The New Zealand Veterinary. 2013.

12. Scope B. Section 2: ADDITIONAL REQUIREMENTS FOR LABORATORIES USING RADIOACTIVE MATERIALS, RADIATION PRODUCING MACHINES, OR LASERS.

13. Organization WH. Safe handling of radionuclides. 1973.

14. Wooley DP, Byers KB. Biological safety: principles and practices: John Wiley \& Sons; 2020.

15. Salerno RM, Gaudioso J. Laboratory biorisk management: biosafety and biosecurity: CRC Press; 2015. [DOI:10.1201/b18446]

16. Nambisan P. Laboratory Biosafety and Good Laboratory Practices. An Introduction to Ethical, Safety and Intellectual Property Rights Issues in Biotechnology. 2017:253. [DOI:10.1016/B9780-12-809231-6.00011-9] [PMCID] 
17. Vijayan V, Ng B. Validating waste management equipment in an animal biosafety level 3 facility. Applied Biosafety. 2016;21(4):185-92. [DOI:10.1177/1535676016666359]

18. Bhatia C. Brass Made Natural Antibacterial Fridge.

19. Berte LM. Laboratory quality management: a roadmap. Clinics in laboratory Medicine. 2007;27(4):771-90.

[DOI:10.1016/i.cll.2007.07.008] [PMID]

20. Wiedbrauk DL, Stoerker J. Quality assurance in the molecular virology laboratory. Molecular methods for virus detection. San Diego, CA:
Academic Press; 1995. [DOI:10.1016/B978012748920-9/50003-0]

21. Burmeister T, Maurer J, Aivado M, Elmaagacli A, Grünebach F, Held K, et al. Quality assurance in RT-PCR-based BCR/ABL diagnostics-results of an interlaboratory test and a standardization approach. Leukemia. 2000;14(10):1850-6. [DOI:10.1038/sj.leu.2401899] [PMID]

22. Organization WH. Laboratory biosafety manual: World Health Organization; 2004.

23. Verderber S. Innovations in hospital architecture: Routledge; 2010. [DOI:10.4324/9780203855751] 
انعطافيذيرى در استفاده از فضاها امكان جابهجايىهاى لازم در صورت نياز وجود داشته باشد. همجنين طراح بايد عواملى از قبيل آناديل مناسبسازى محيط آزمايشآهها براى افراد و دستخاههاى متفاوت

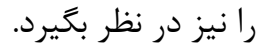

تطابق اصل انعطافيذيرى در زيشبينى زيرساختهاى

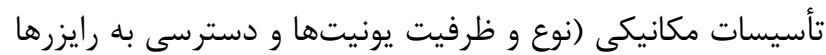
و موارد مشابه) و الكتريكى (ظرفيت سيستم و جانمايى يريزها)

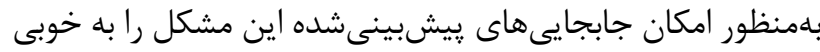

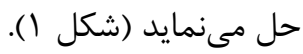

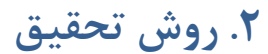

روش شناسى اين يزوهش بر اساس روش توصيفى و تحليلى

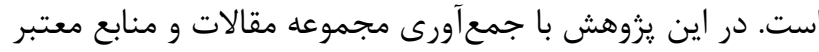

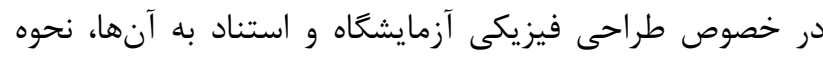
طراحى اين فضا بيان كرديده است. منابع كردآورىشده تحمليليل شده و مورد استناد قرار خرفته است.

س. اجزا و مر احل طراحى معمارى در آزمايشعاه يزشكى سـى

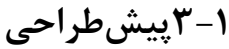

يكى از اصلىترين مراحل طراحى آزمايشكاهها يِشطراحى

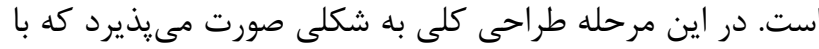

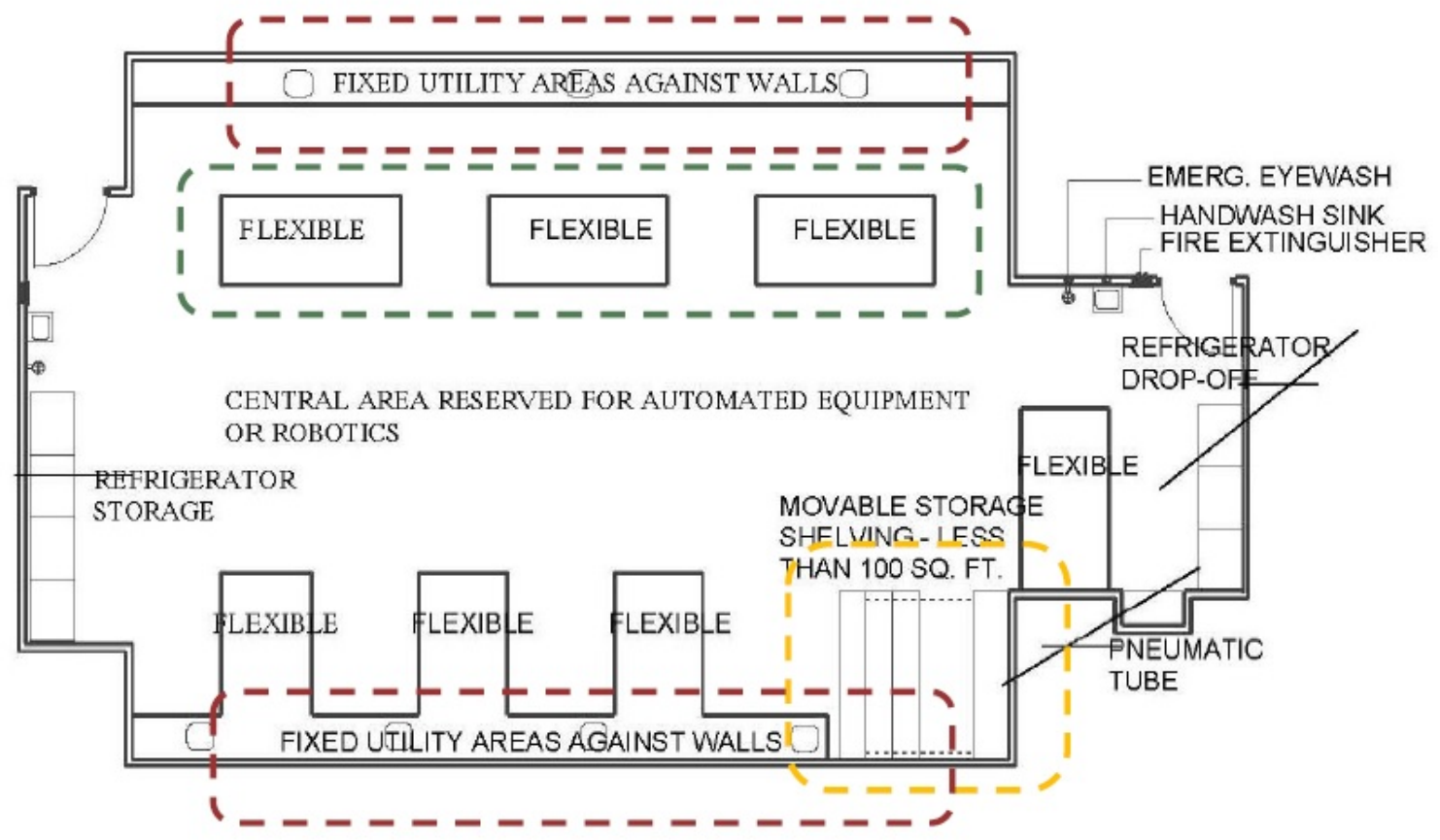

شكل ا. نماى شماتيك از فضاى كارى آزمايشكاه براى ايستًاهماى كارى متحرى و منعطف (T)

\section{فضاى مجاور و جسبيده به هم Adjoining}

براى فضاهاى مجاور و جسبيده به هم مىتوان به بخشهاى فنى از جمله بخشهاى بيوشيمى، هماتولوزى، ايمونولوزى و

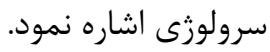

\section{فضاى نزديك به يكديكر (Adjacent Space)}

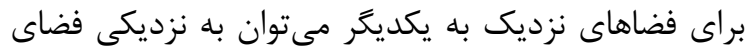
يذيرش و نمونه

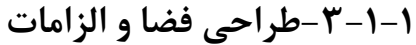

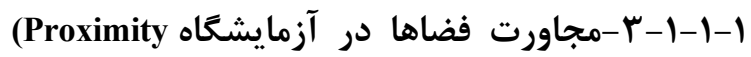

Space)

بخشهاى فنى مرتبط در يك آزمايشًاه يزشكى بهتر است

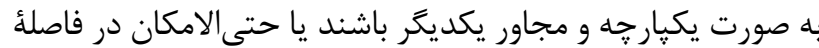
نزديك به هم قرار گيرند، در عين حال برخى فضاهاى آزمايشعاه

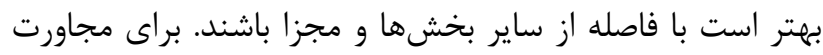
فضاها در آزمايشخاه مىتوان سه حالت زير را در نظر كرفت: 
از نكات و الزامات مربوط به نيازهاى حركتى افراد كمتوان و

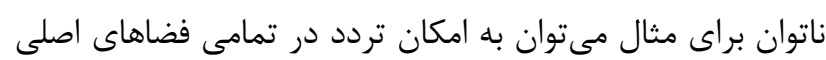

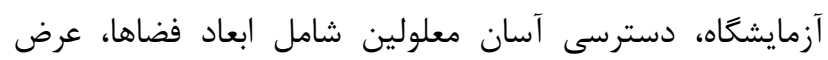

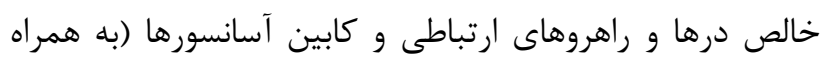

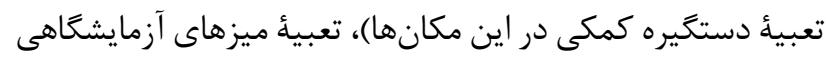

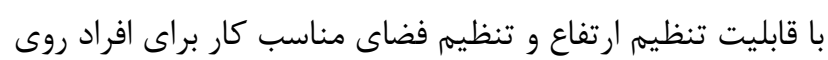

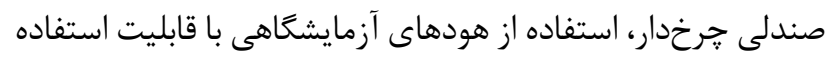

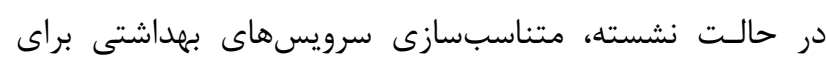

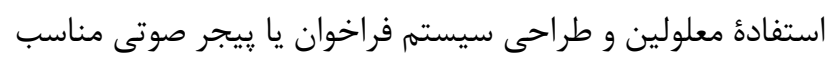

$$
\text { براى افراد داراى مشكلات شنوائى اشاره كرد. }
$$

بديهى است كه تعداد اين امكانات در سطح آزمايشكاه، به

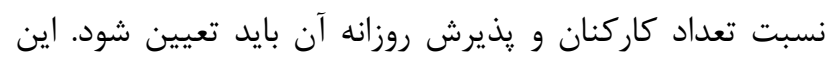

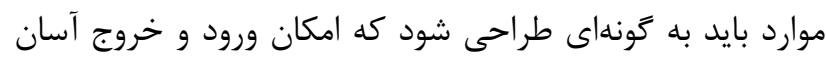

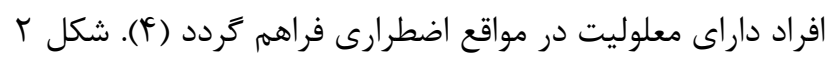

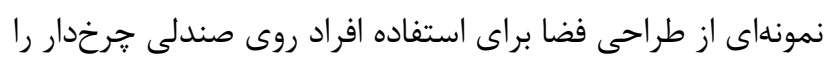

$$
\text { به تصوير كشيده است (ه). }
$$

\section{فضاى مجزا (Separated Space)}

براى فضاهاى مجزا از ساير فضاها مىتوان به فضاهاى

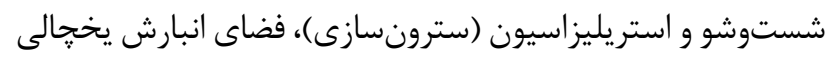

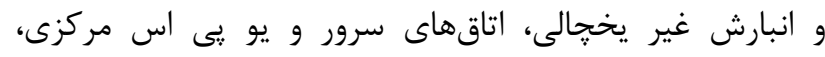

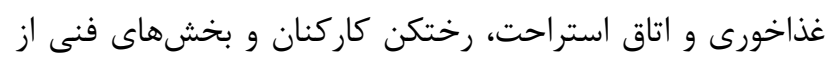

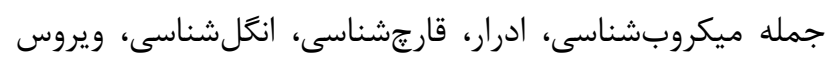
شناسى، آزمايشخاه مولكولى و ساير موارد اشاره نمود (َآ). ץ-1-1-ب-الزامات در تأمين نيازهاى حركتى افراد

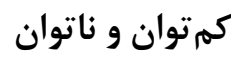
توجه به نيازهاى حركتى افراد كمتوان و ناتوان (معلول) در مقياس شهر و ساختمان از حداقل استانداردهاى كشورهاى

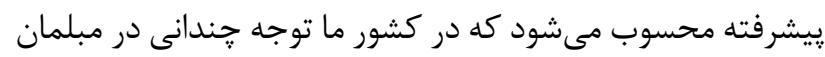

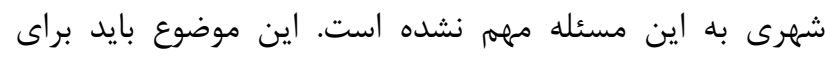

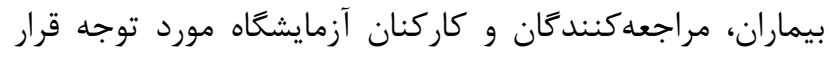

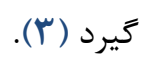

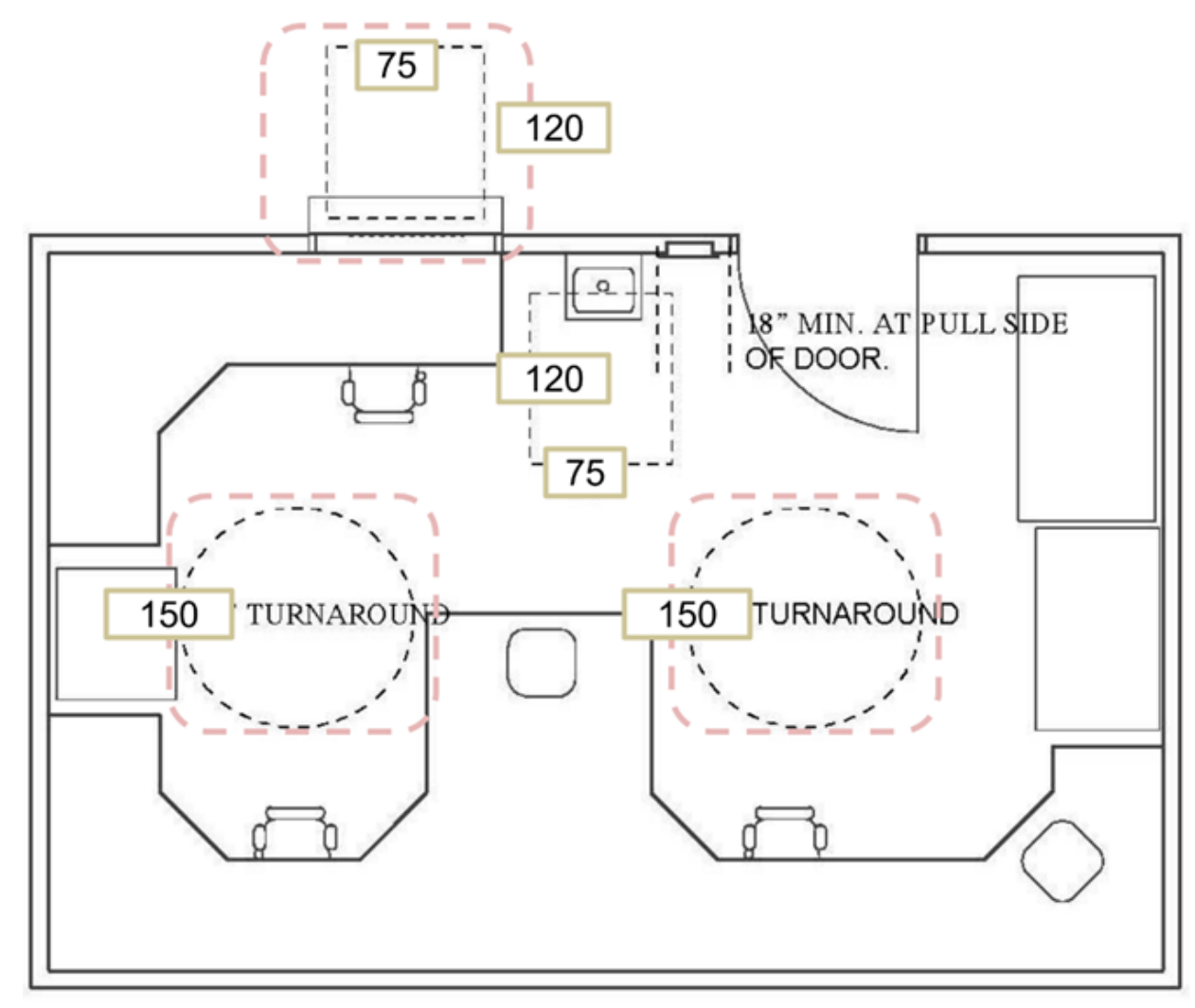

شكل r. حداقل ابعاد طراحى ميزكار افراد معلول و سالمند (ه) 
مهيا باشد و با بررسى دقيق و كسب اطلاعات همه جانبه، مساحت

نسبى لازم براى كسترش فضا در آينده در نظر كرفته شود (؟). در حال حاضر بر اساس آييننامئ تأسيس و اداره امور

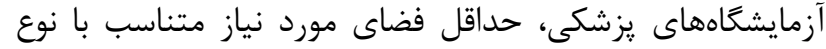

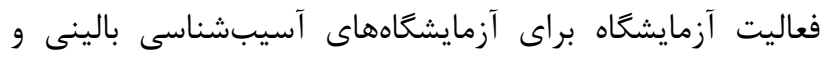

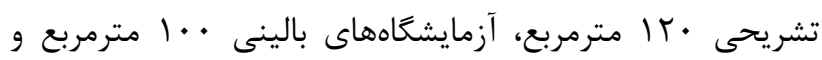

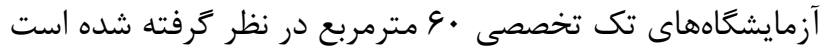

در آزمايشكاه بايد فضاى مناسب براى انجام كارها در نظر كرفته شود به نحوى كه از كيفيت، ايمنى و كارايى خدمات، اطمينان حاصل شده و سلامت و ايمنى كاركنان، بيماران و مراجعين تضمين آناني

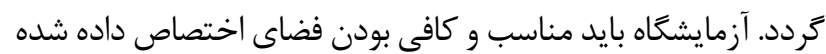
براى انجام فعاليتها را ارزيابى و تعيين نمايد (F). فضاى كارى ناكافى يا طراحى نامناسب فضاى فيزيكى

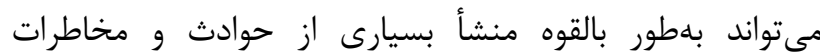

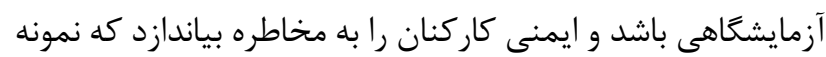

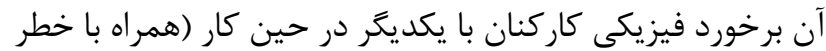
آلودكى به مواد عفونى و شيميايى و خطرناك) يا برخورد كار كنان

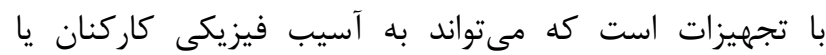

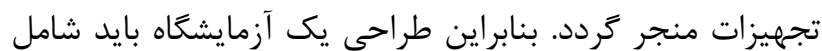
طراحى بخشهاى مورد نياز، مساحت آنها و نحوهُ قراركيرى آنها

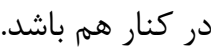

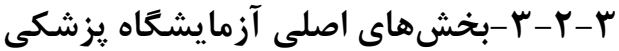

هر آزمايشكاه يزشكى به بخشهاى مختلفى نياز دارد. از جملة اين بخشها مىتوان به سالن انتظار مراجعان، يذيرش و

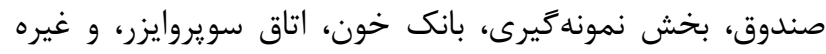

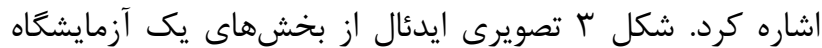
يزشكى را به تصوير كشيده است.

\section{Yuality (}

(of Laboraory Space

مههمترين عامل تأمين كنندة كيفيت در يك فضا وابسته به اين موضوع است كه آن فضا با نوع كاربرى متناسب است يا خير.

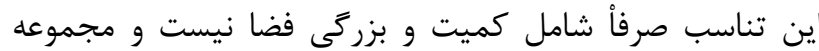

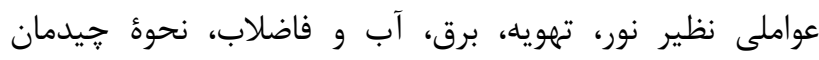

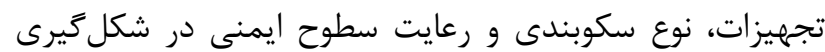
كيفيت كلى يك فضا نقش دارند. وجود ستونها و ديوارها و بارتيشنهاى غيرضرورى مىتواند در كاهش كيفيت يك فضا مؤثر

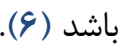

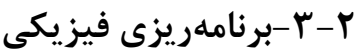

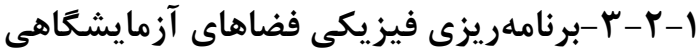

در فرآيند طراحى، يس از يِيشطراحى به برنامهريزى

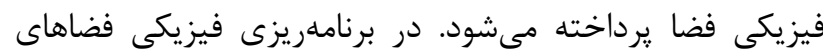
آزمايشكاهى با فهرست كردن فضاهاى مورد نياز، شرح كاربرى و ورئي نظام ارتباطى آنها با يكديكر مساحت مورد نياز بررسى مىشود (؟ّ).

\section{r-r-r-r-r}

اغلب حداقل فضاى فيز يكى كه در بدو افتتاح آزمايشكاه كافى بلنظر مىرسد با توسعه و روند روبهرشد آزمايشكاه و تعريف آزمايشها و تجهيزات جديد و بخشهاى فنى و كاركنان جديد،

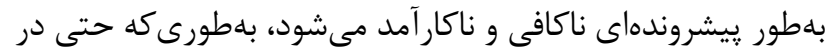

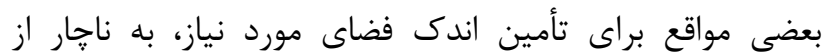
راهروهاى باريك آزمايشكاه براى كاربرى فنى استفاده مىشود.

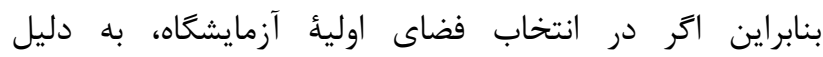

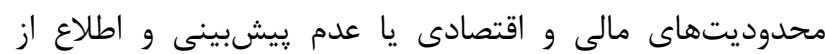
گَسترش و توسعه فعاليتهاى آزمايشگاه در آينده، حداقل فضاى

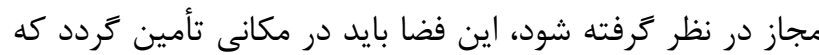
امكان الحاق فضاهاى جانبى و يا طبقات فوقانى در مجاورت آن آن 


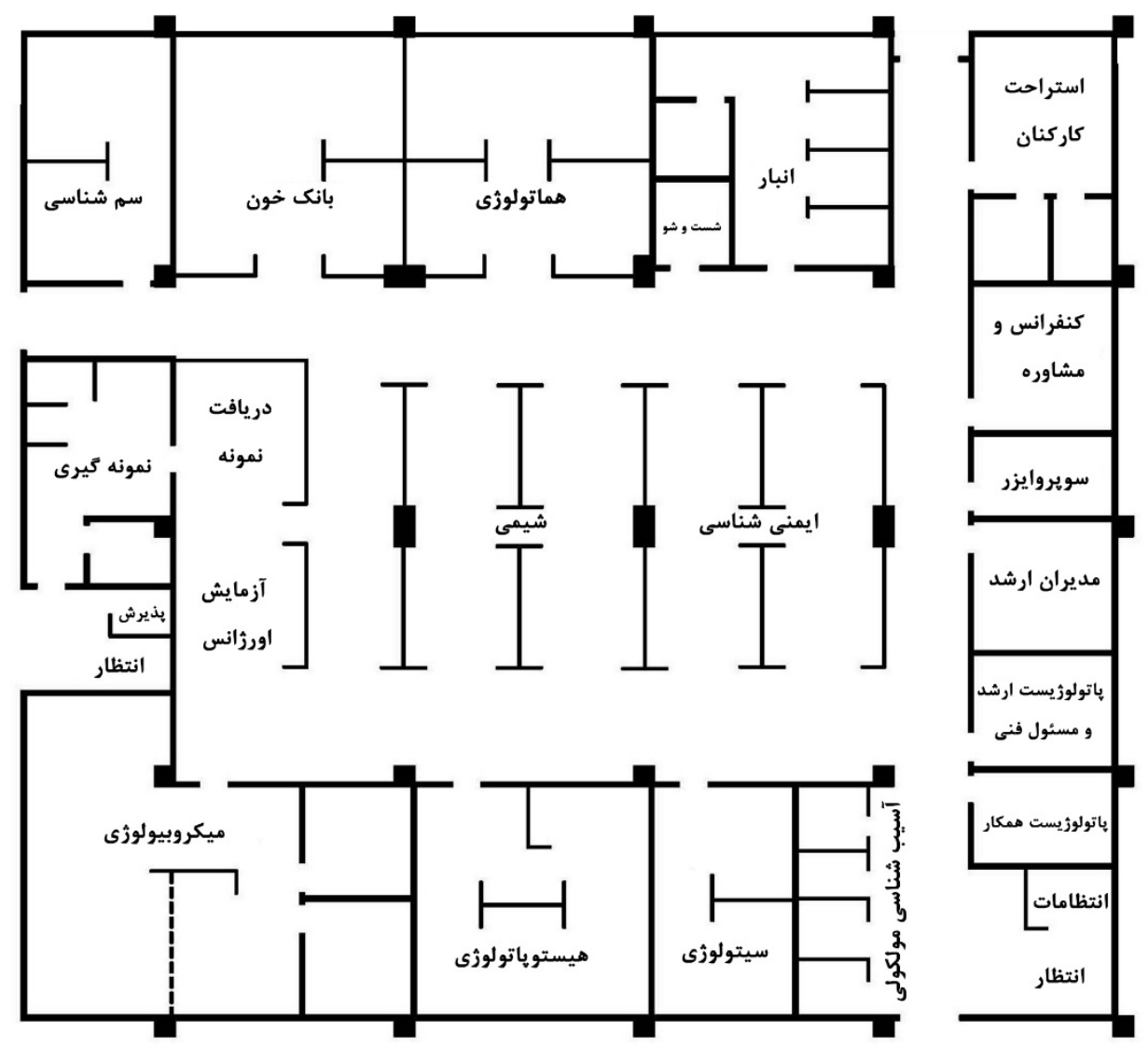

شكل r. نماى شماتيك از فضاهاى مختلف آزمايشكاه بر اساس شاخص HMI (Y)

ه-Y-Y-Y-Yنترل و نظارت بر فضاى فيزيكى آزمايشعاه

علاوه بر كميت و كيفيت فضا، طراحى سيستمهاى

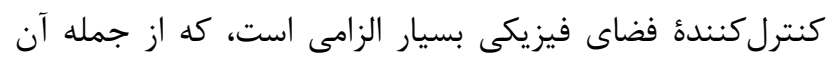

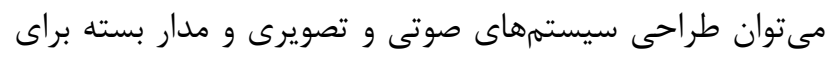

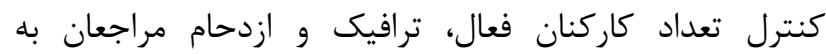

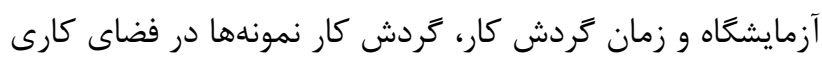

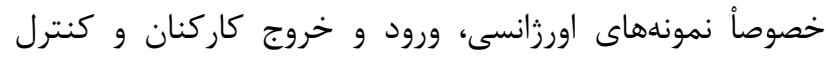
اينترنتى فضا از راه دور را نام برد.

צ-r-r-r-اضافه يا حذف نمودن فضاى فيزيكى در آزمايشگاه

در شرايط ايدهآل همانطور كه نياز به فضا در آزمايشكاه

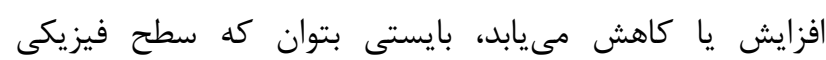

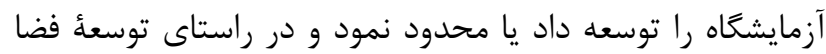
بايد يِشبينى اين موضوع كه فضاهاى جانبى بالقوه آزمايشخاه قابل

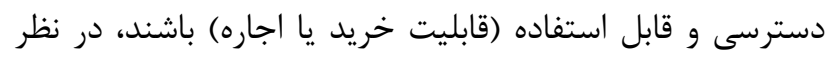

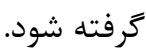

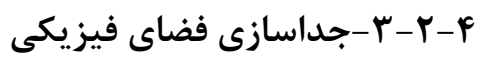
جداسازى و سازماندهى فضاى فيزيكى بحث برانكَيزترين و

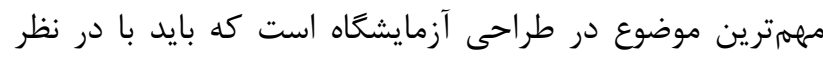

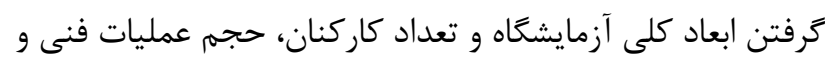

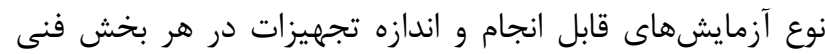

تعريف شود (V).

برخى از فضاها الزامأ بايستى ايزوله و مجزا از ساير فضاهاى

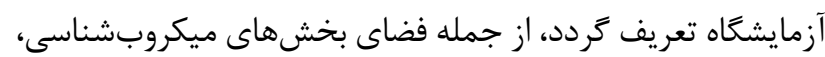
قارجشناسى، شتوشو و استريليزاسيون. در ضمن فضاهاى ادارى و دفترى و نمونهبردارى بهتر است از ساير فضاها مجزا باشد.

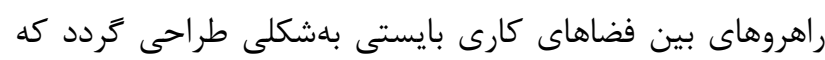

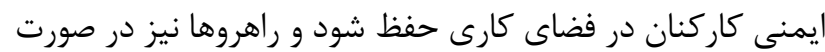
امكان بهن و عريض باشند (1). حداقل عرض استاندارد راهرو و ميزهاى آزمايشگاهى بر

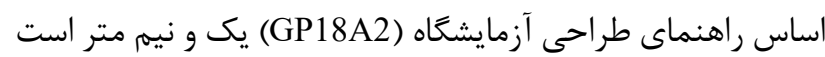
كه در شكل f انشان داده شده است (1). 

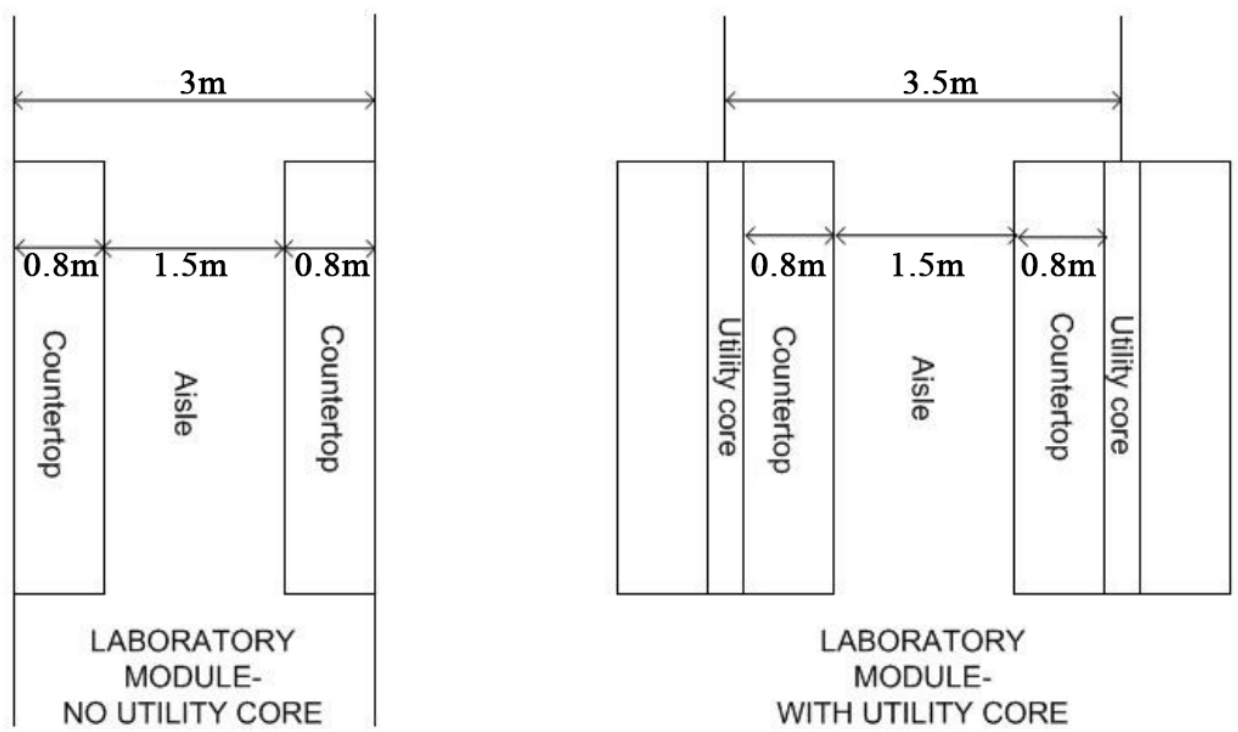

شكل ؟. حداقل عرض ميزهاى آزمايشًاهى بر اساس راهنماى طراحى آزمايشكاه (())

بخشهاى بالينى بيمارستان به واحد جداسازى نمونهها و از واحد

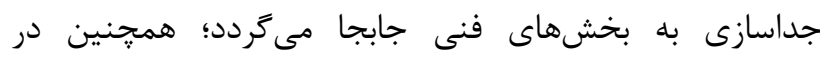

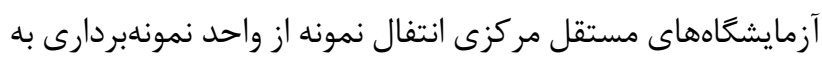
جداسازى و بخشهاى فنى انجام خواهد شد. بهطور كلى از مزاياى آنسي

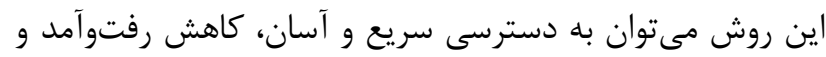
تردد بين بخشهاى مختلف، كاهش هزينه و انتقال ايمن نمونه

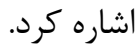



فيزيكى

در فهرست تجهيزات تعريف شده در هر فضاى فيزيكى به

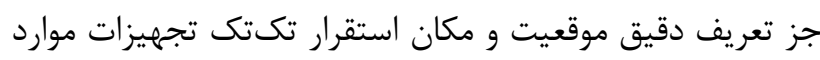
زير بايد بهطور دقيق تعريف و ثبت گردد (9): •• ابعاد تجهيز يا دستخاه (طول و عرض و ارتفاع دقيق دستكاه) همراه با حداقل فضاى جانبى مورد نياز هر تجهيز (فاصله تجهيز از ديوار و طرفين) •• تعريف ابعاد تجهيزات جانبى لازم براى هر دستگاه نظير

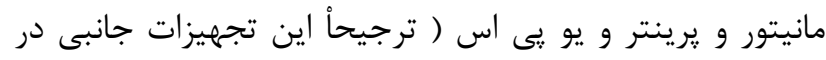

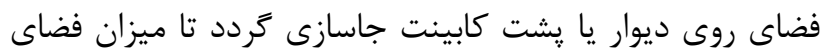

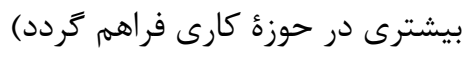
•• تعريف منابع تغذيه (ولتاز و جريان مورد نياز دستكاه) و سيستم آب و فاضلاب دستخاه

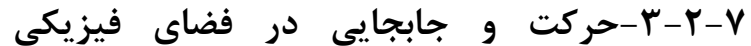
آزمايشحاه بزشكى

ارزيابى مسير حركت و جابجايى كاركنان و بيماران و ودمان

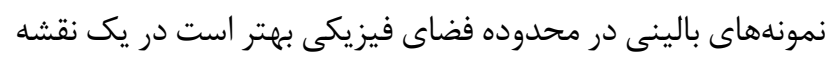
و نمودار ترسيم كردد و محدوديتهاى تردد براى هر كروه مشخص برد برد و معين كردد؛ از جمله محدوديت حركت و تردد بيمار به فضاهاى

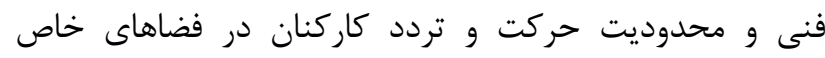
مشخص شود (بهعنوان مثال تردد كاركنان فاقد صلاحيت در بخش ترد مايكوباكتريولوزى يا ميكروبشناسى تخصصى يا بخش مولكولى به إنها

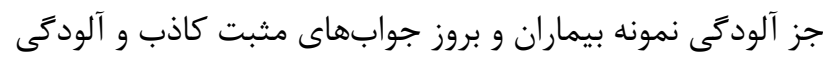

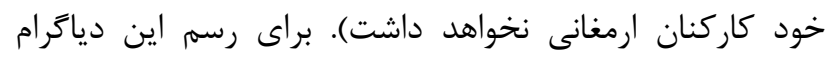

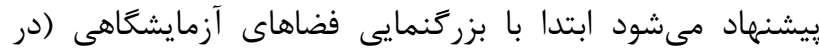

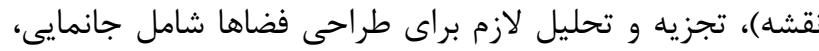

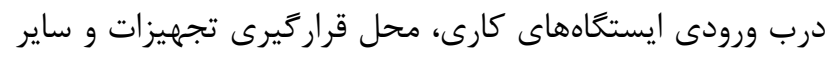

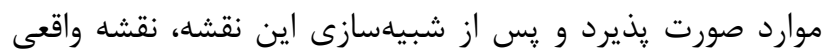

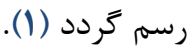

\section{1-}

\section{هواى فشرده (سيستم ينوماتيك)}

طراحى سامانه انتقال نمونه با استفاده از هواى فشرده در

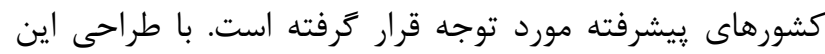
سيستم در بيمارستانها، نمونهاى آزمايشخاه به راحتى از 
بسيارى از مواد رايج در آزمايشگاه حلالهاى شيميايى مانند

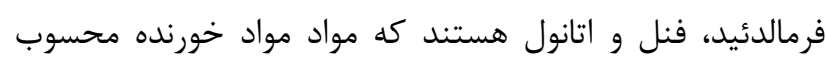

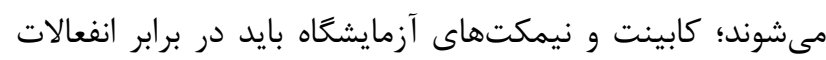

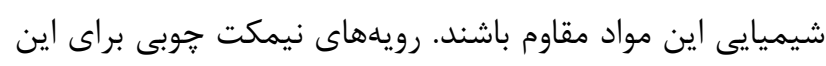

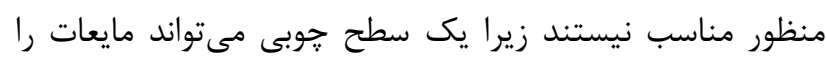

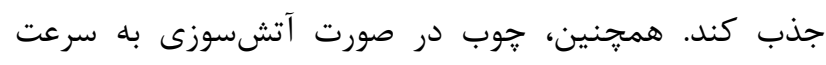

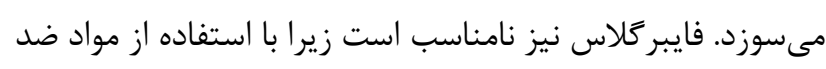

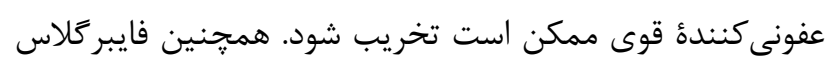
در هنكام سوختن دود سمى آزاد مى كند (I) (I).

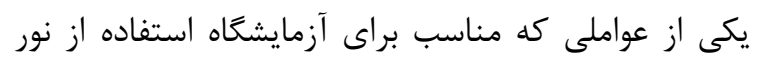

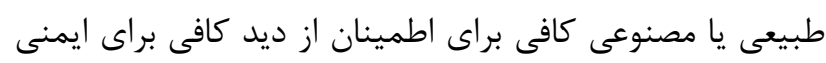
عملياتى است (r) (1).

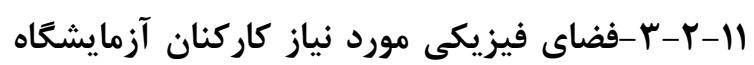
يزشكى

كاركنان از عناصر اصلى و مهمم هر آزمايشگاه يزشكى هستند

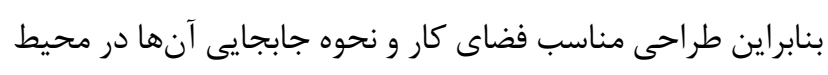

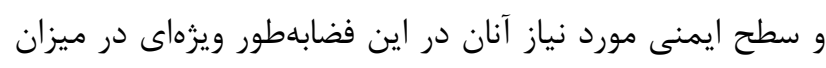
رضايتمندى كاركنان و كيفيت نهائى و عملكرد كلى آزمايشخاه مؤثر خواهد بود.

محاسبه مجموع فضاى كارى (فنى) موردنياز آزمايشعاه

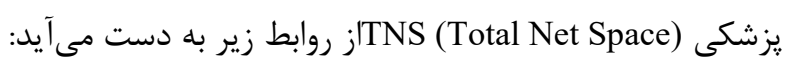
TNS $=$ BWS + FMI

$\mathrm{BWS}=[(\mathrm{AE}+\mathrm{CWS}) \times(\mathrm{CD}+\mathrm{AW})]$

علامت اختصارى فضاهاى فيزيكى مختلف آزمايشكاه يزشكى مورد استفاده در اين فرمول در جدول إبيان شده است.

r-ץ-ايمنى، افزايش بهرهورى و تجهيزات لازم

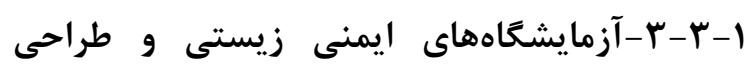
الزامات آنها

طبقلبندى براساس سطوح ايمنى زيستى براى فراهم آوردن

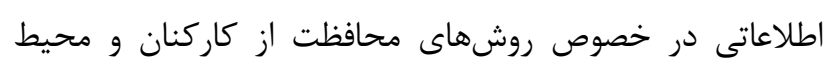

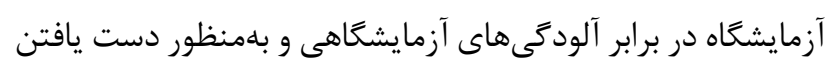

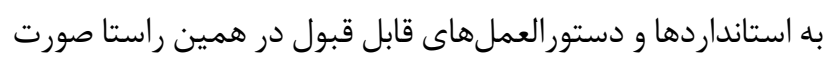

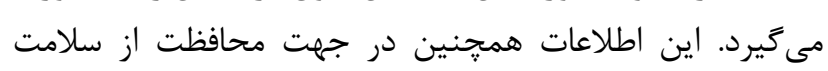

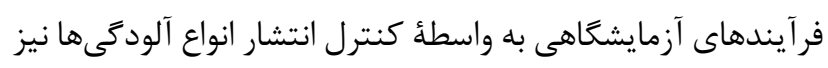

•• تعريف نحوه دسترسى به فضاى پشت و جانبى دستگاه

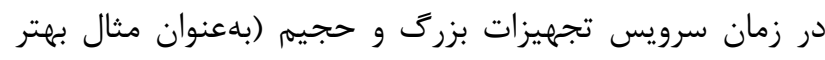

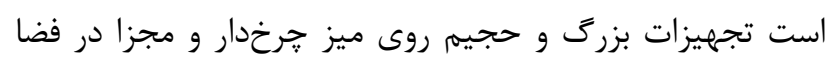

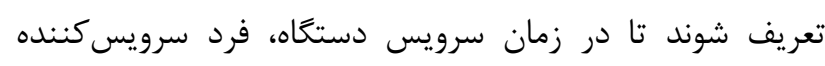

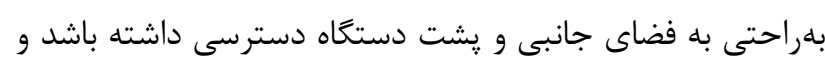

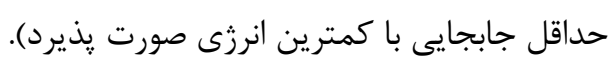

• • ممنوعيت مجاورت يك تجهيز با برخى تجهيزات (بلعنوان مثال ممنوعيت مجاورت سانتريفوز و ميكروهماتوكريت بات بات برخيز سل كانتر و...) (بهعن مئال)

•• عدم مجاورت تجهيزات حساس به كرما با سيستمهاى كرمايش آزمايشعاه (خصوصاً ميز كار الايزا).

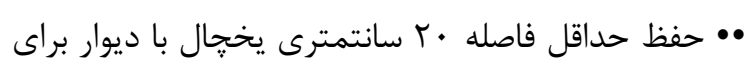
تبادل حرارت

•• مكانيابى مناسب براى تجهيزاتى كه توليد كرماى بالا

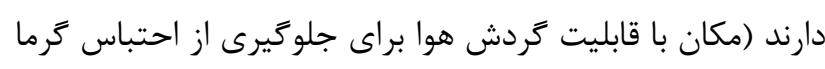

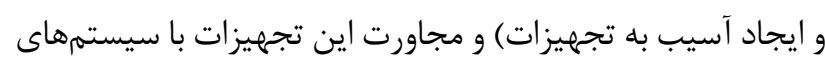
خنك كنندة استاندارد (•) (1).

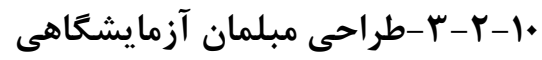

مبلمان آزمايشًاهى بايد داراى سطوح صاف و غير متخلخل

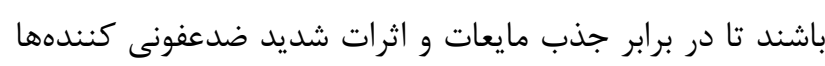

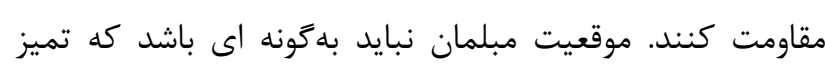

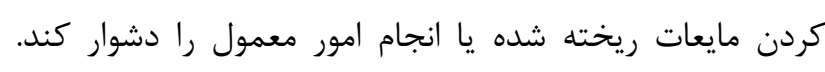

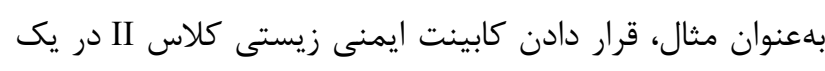

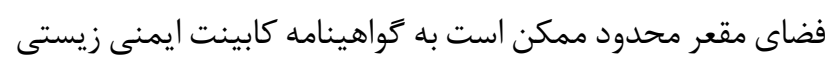

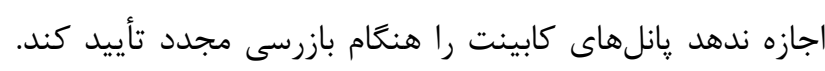

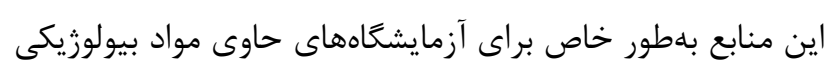
و راديواكتيو اعمال مىشود (11). مبلمان آزمايشًاهى بايد داراى سطوح صاف و و غير متخلخ الخل

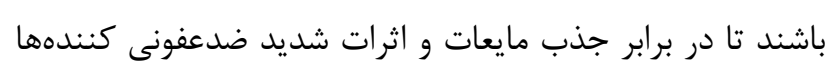

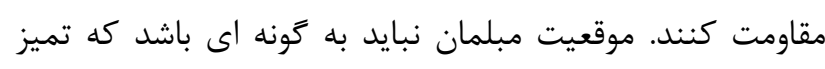

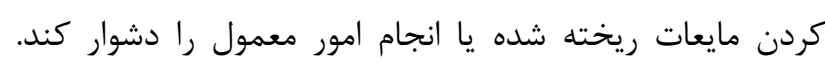

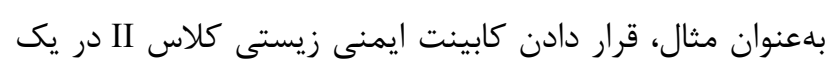

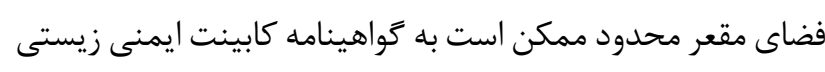

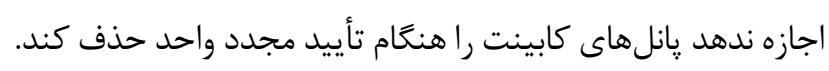

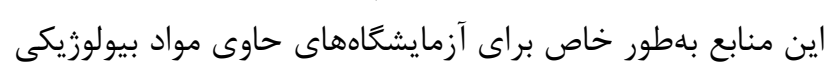
و راديواكتيو اعمال مىشود (1). 
آزمايشكاهى و كنترل انتشار آلودگىها، در آزمايشكاههايى كه از مواد

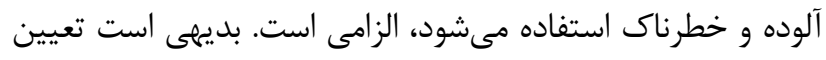

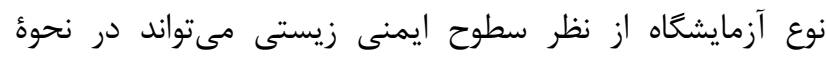
برنامهريزى و طراحى آزمايشخاه تاثير كذار باشد.
كاربرد دارد. در واقع هدف اصلى از مباحث ايمنى زيستى در

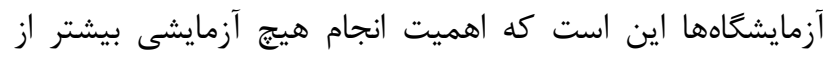

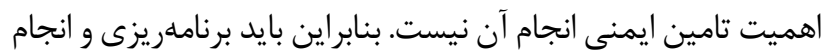

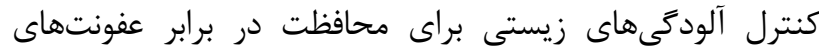

جدول (. علامت اختصارى فضاهاى فيزيكى مختلف آزمايشكاه يزشكى (^)

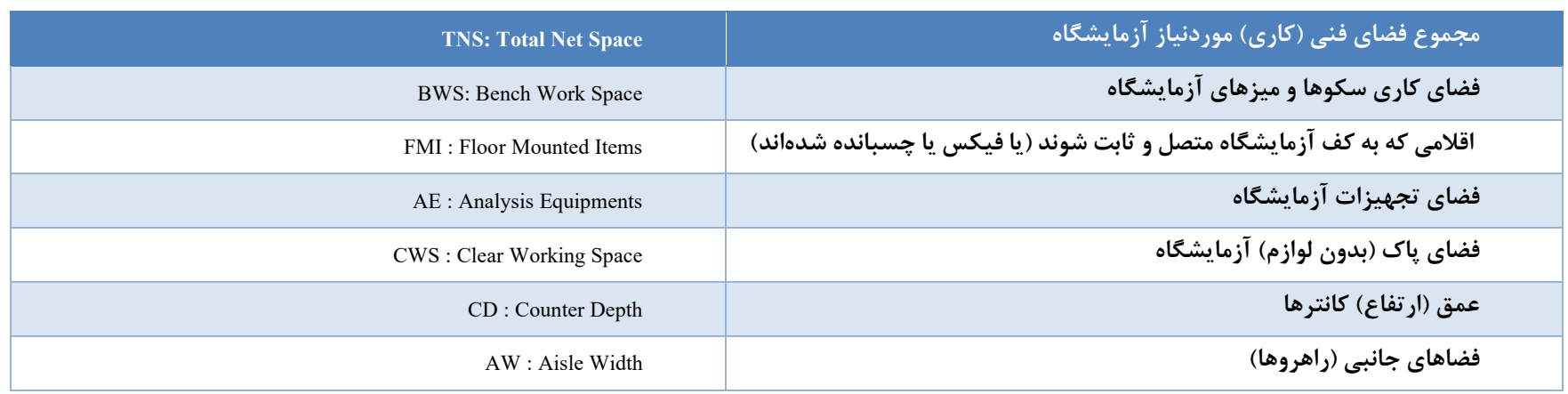

\section{r-r-1 - آ- آزمايشعاه سطح ا ايمنى زيستى و الزامات آن}

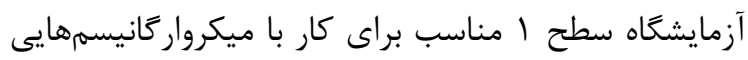
است كه در آن سطح خطر يايين است و كاركنان آزمايشعاه مطابق آنايق آناهيق

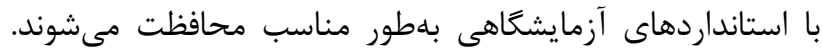

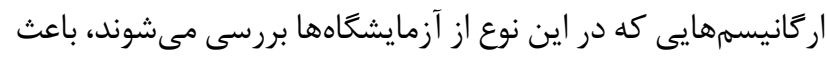

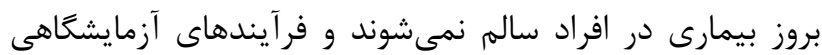
ممكن است در فضاى باز (خارج از هود) انجام شوند. تهويئ اين آزمايشگاه را مىتوان به صورت طبيعى تامين نمود. سطح l ايمنى زيستى معرف آزمايشًاههايى است كه از يك سطح ابتدايى ايمنى برخودار بوده و مبتنى بر استفاده از شيوههاى

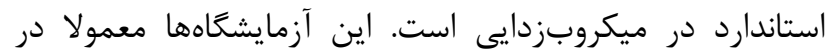

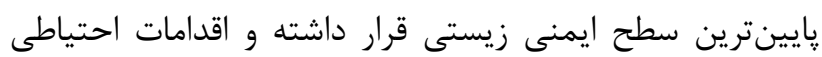
شامل شستوشوى منظهم دستها و استفاده از وسايل حفاظتى مانند دستكش، سينك مجزاى شستوشو، مواد ضدعفونى كننده مناسب براى ضدعفونى سطوح و دستها لازم است. همجنين محيطهاى حاوى كشت ميكروبى و پِماندها بايد اتوكلاو شوند (هائ (1).

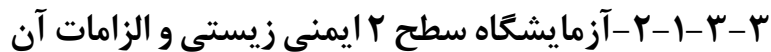

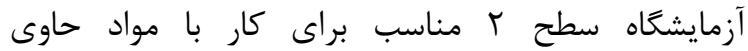

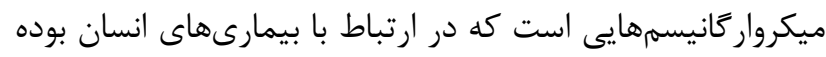

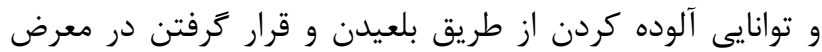
غشاى مخروطى داشته و در محيط اطراف وجود دارند. با استفاده

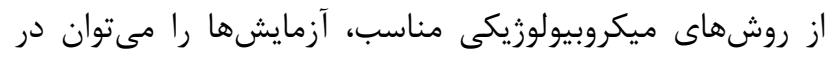

بله عبارتى ايمنى زيستى دامنه كسترداى است. عوامل محافظت ايمنى زيستى شامل وسايل حفاظت شخصى، كابيتهاى زئى جهار Fانه ايمنى زيستى و عوامل كَندزدا، روشهاى تشائ تشخيصى شامل

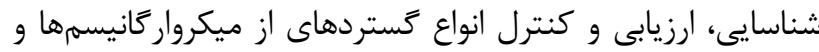

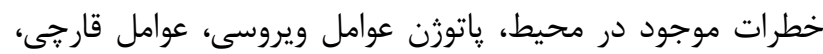
عوامل مشترك بين انسان و حيوانات، تكياختهها و ناقل هاى انتقال زن و مديريت بيوريسك از جمله مقر رات، دستورالعملها منطبق با

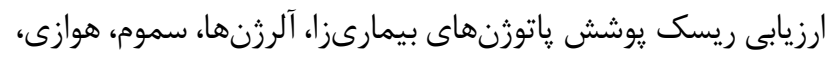
يزشكى كار، ايمنى بيولوزيكى را در برمى گيرد (If).

بر اساس تعريف سازمان بهداشت جهانى، ايمنى زيستى

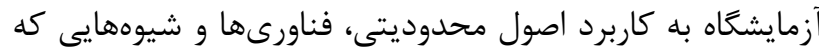

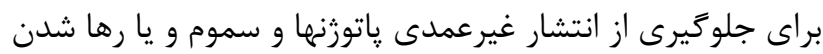
آنها در محيط اطلاق مىشود و امنيت زيستى آزمايشگاه، به آنها مجموعه اقدامات و روشهاى امنيتى بهكاربرده شده بلهوسيله

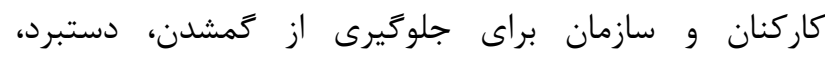
سوءاستفاده، انحراف يا انتشار عمدى ياتوزنها و مواد سمى اطلاق

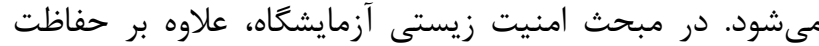
فيزيكى اقداماتى از قبيل مديريت كاركنان، كنترل و حسابرسى إنى

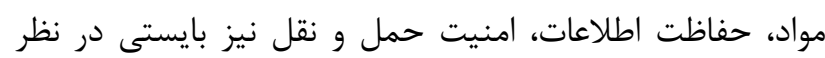
كرفته شود. با توج به مفاهيم فوق، معماران و طراحان مراكز بهداشتى و درمانى بايد در طراحى آزمايشعاه و يا بيمارستان به به به بهان اين نكات توجه نمايند (Q) (1). 
FERS- وروه مىتوان به , SARS-COV- 1 SARS-CoV-2

COV

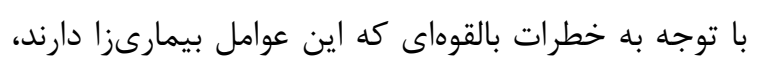

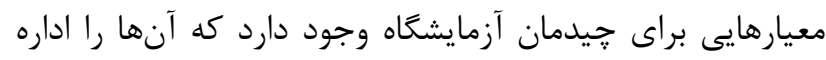

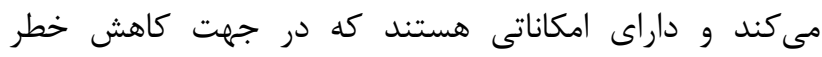

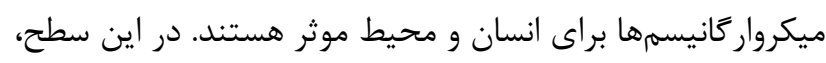
فرآيندهاى آزمايشًاهى در فضاى محبوس و كنترل شده انجام

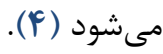

از نظر نوع آزمايشكاه، آزمايشكاههاى تشخيصى تخصصى و

$$
\text { تحقيقاتى را دربرمى گيرند. }
$$

سطح بَ ايمنى زيستى معرف آزمايشخاههايى است كه استفاده

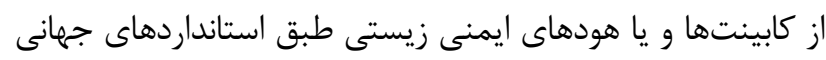
و از حفاظهاى ثانويه همجون سيستم فشار هواى منفى الزائى إنى است. اين سطح از آزمايشخاه از نظر عمليات و عملكرد آزمايشخاهى،

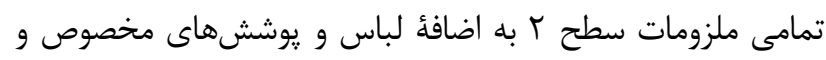

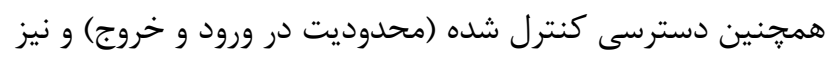

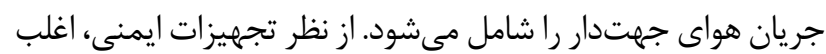

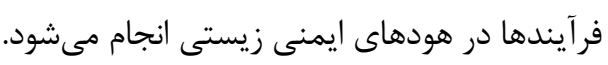

نماى شماتيك از يك آزمايشعاه سطح بَ ايمنى زيستى شامل

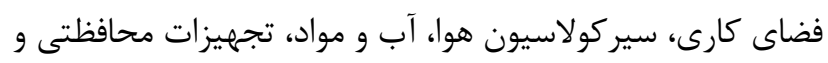
ورود و خروج افراد در شكل ه نشان داده شده است (19).
فضاى باز انجام داد. البته در صورتى كه خطر توليد ذرات معلق در هوا وجود داشته باشد، بايد از هود ايمنى زيستى استفاده نمود. از نظر نوع آزمايشخاه، آزمايشگاههاى ارائه دهنده خدمات

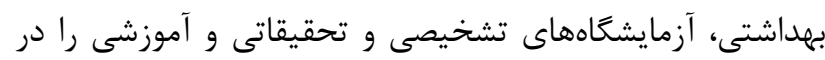

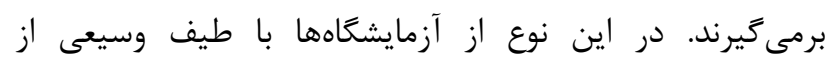

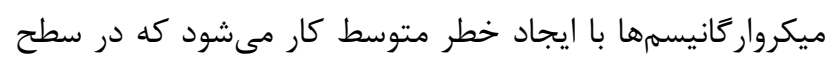

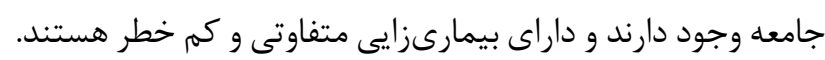
در آزمايشگاههاى سطح r در صورتى كه حين انجام

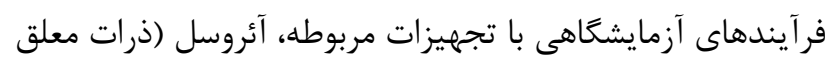

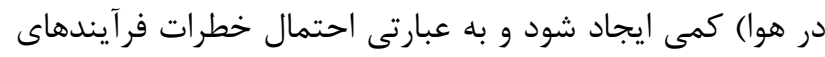

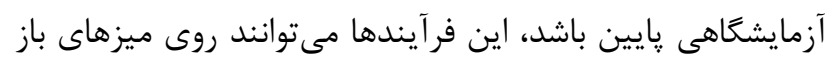

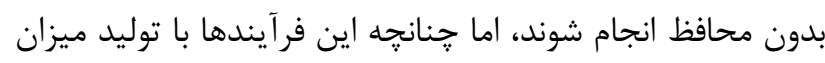

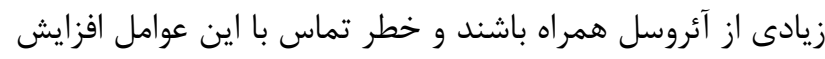
يابد، بايد از هودهاى ايمنى زيستى استفاده شود.

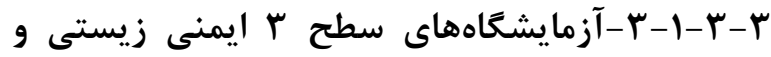
الزامات آن آزمايشعاه سطح r مناسب براى كار روى ميكروار كانيسمهاى

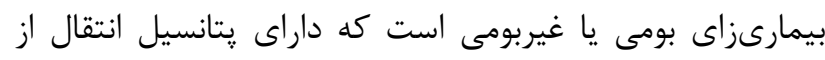

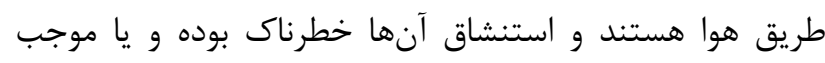

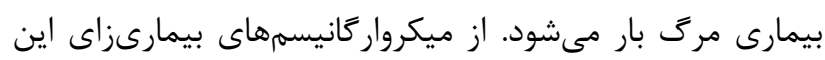

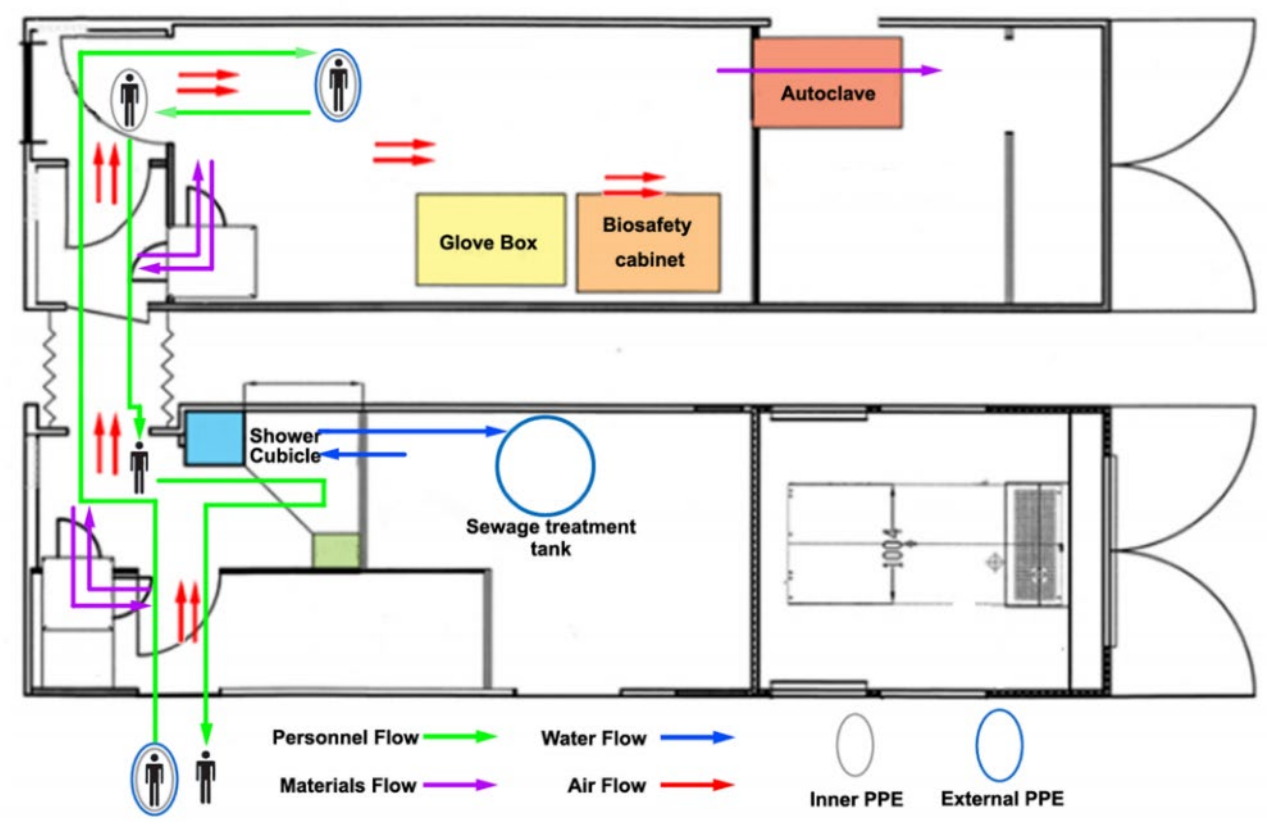

شكل ه. نماى شماتيك از جانمايى هود و كَرش هوا، آب و مواد و ورود و خروج كاركنان در آزمايشكاه سطح ب ايمنى زيستى (T () 


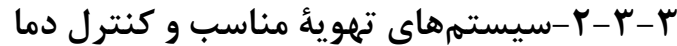
در بسيارى از مواقع تهوية مطبوع، سرمايش و كرمايش به

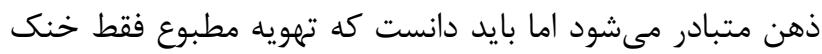
كردن يا گرم كردن نيست. با استفاده از فناورى تهويه مطبوع

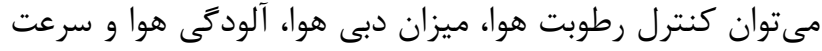

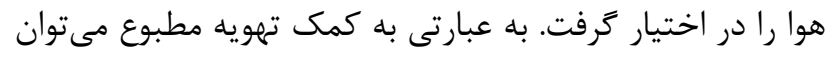
حتى ذرات معلق در هوا و آلودگى هاى موجود در هوا را از بين برد برد رطوبت زائد را از هوا كرفت و ميزان گرما يا سرماى مورد نياز محيط آنائ

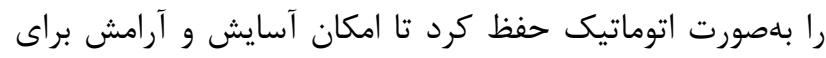

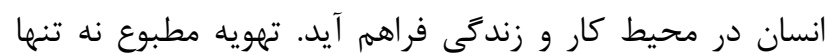
كاربردهاى عمومى دارد بلكه از آن در مكانهاى حساس مثل

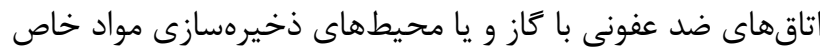

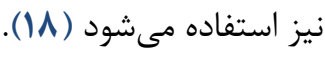

\section{r-r-r-r-rمقررات ايمنى كار با DNA نوتركيب}

تكنولوزى DNA نوتر كيب شامل تلفيق ماده زنتيكى از منابع

مختلف و ايجاد يك اركانيسه تغيير يافته زنتيكى GMO است كه

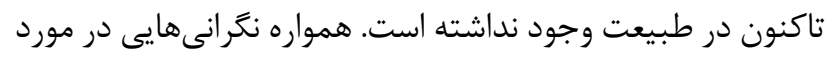
خصوصيات نامطلوب و غير قابل ييشبينى جنين اركانيسمهايى به خصوص در صورت آزاد شدن ناگمهانى آنها در طبيعت وجود دارد

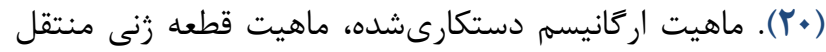

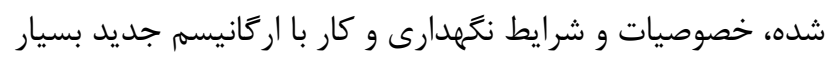
مهمم است. دستورى زنتيكى ممكن است خصوصيات جديد و ناشناختهاى را به اركانيسم ميزبان بدهد. بنابراين رعايت اصول

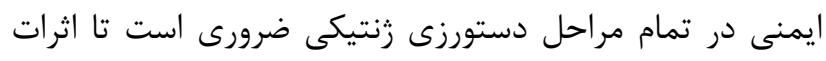
منفى اين مطالعات به حداقل برسد (19).

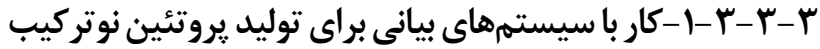

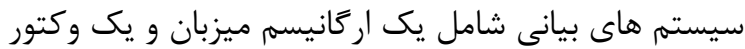

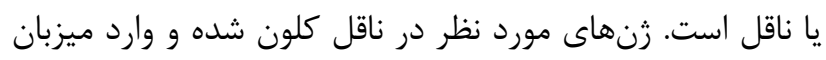
مىشود Escherichia coli كى از معمولترين باكترىهايى است كه بهعنوان ميزبان بيانى استفاده مىشود. اين باكترى غير ياتوزن

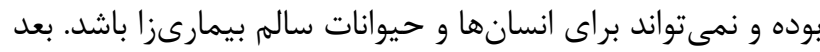

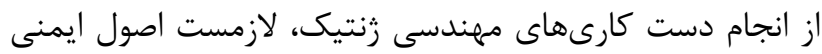

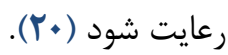

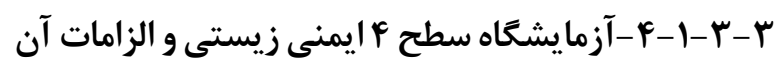

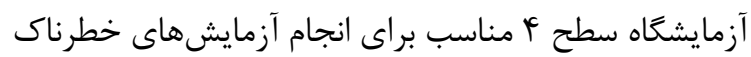

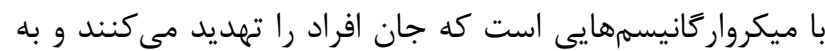
سرعت در جامعه يخش مىشوند. انتشار اين عوامل بيمارىزا از طريق ذرات معلق در هوا، به صورت بسيار خطرناكى، عامل تهديد

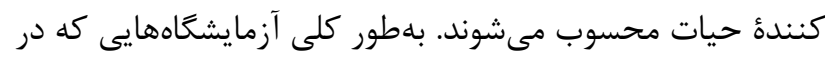
آنها كشت ويروس صورت مى گيرد، سطح عا بوده و اين سطح از از

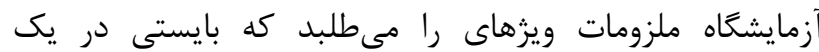

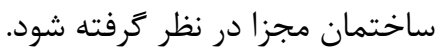

از نظر نوع آزمايشكاه، شامل واحدهاى تشخيصى است كه بلمنظور تشخيص عوامل بيمارىزاى خطرناك (كشت ميكروار كانيسم)

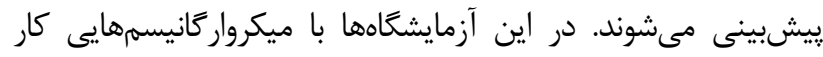

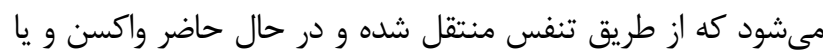
روش درمانى مناسبى براى آنها وجود ندارد (F). از ميكرواركانيسههاى بيماريزاى خطرناك و تهديد كننده حياط اين كَروه مىتوان به تب خونريزى دهنده ويروسى مانند ويروس ماربورى، ويروس ابولا، ويروس لاسا، تب خونريزى دهن دهنده

كريمه كنگ و و موارد مشابه اشاره كرد (F). سطح ₹F ايمنى زيستى معرف آزمايشكاههايى است كه از نظر

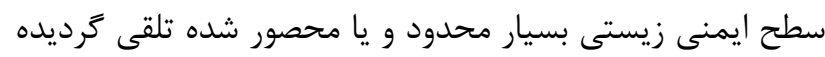
و ساختمان آن كاملا در فضايى مجزا قرار مى بـيرد. استفاده از

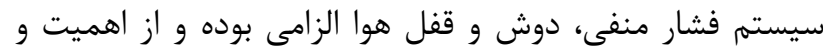
حساسيت بالايى برخوردار هستند.

از نظر عمليات و عملكرد آزمايشًاهى ملزومات سطح ب همراه با سيستم قفل هوا در محل ورود، دوش در محل خروج و نيز مديريت خاص براى دفع صحيح يسماندها را شامل مى تردد. از نظر تجهيزات ايمنى، استفاده از هود ايمنى زيستى كلاس؟

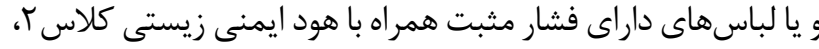

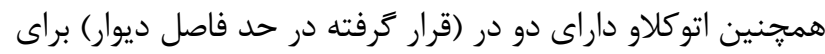
خروج مواد و نيز هواى فيلتر شده را شامل مىشود داري (1). نماى شماتيك از سطوح جهار كانه ايمنى زيستى و امكانات، تجهيزات و تاسيسات آنها در شكل و نشان داده شده است (IV). 


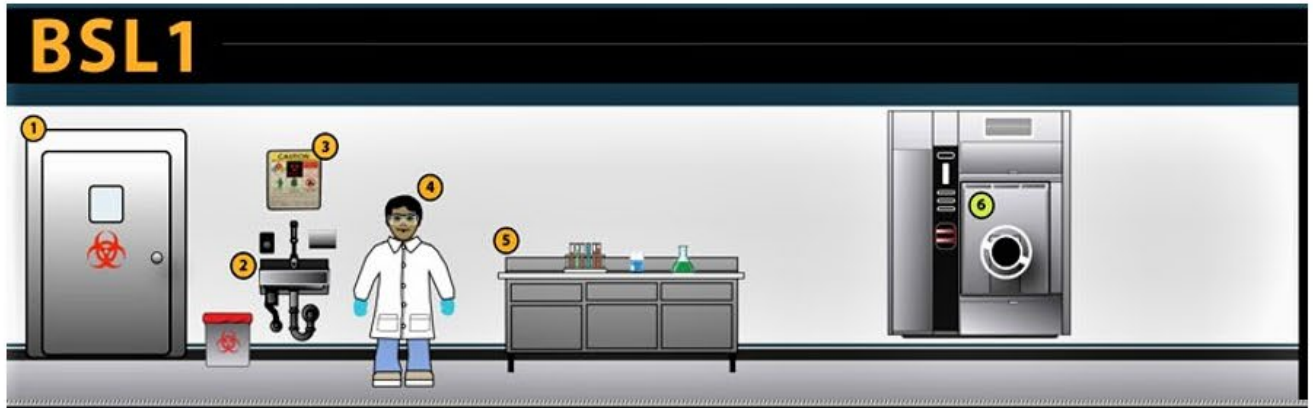

\section{BSL2}

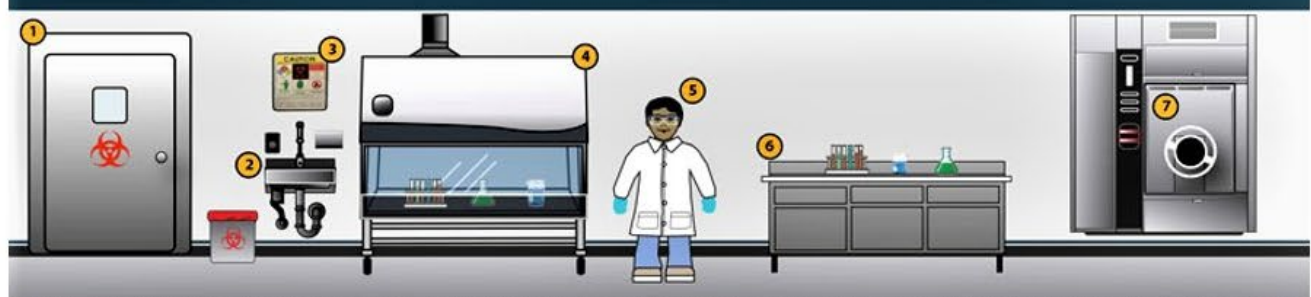

\section{BSL3 (WITH RISK-BASED ENHANCEMENTS)}

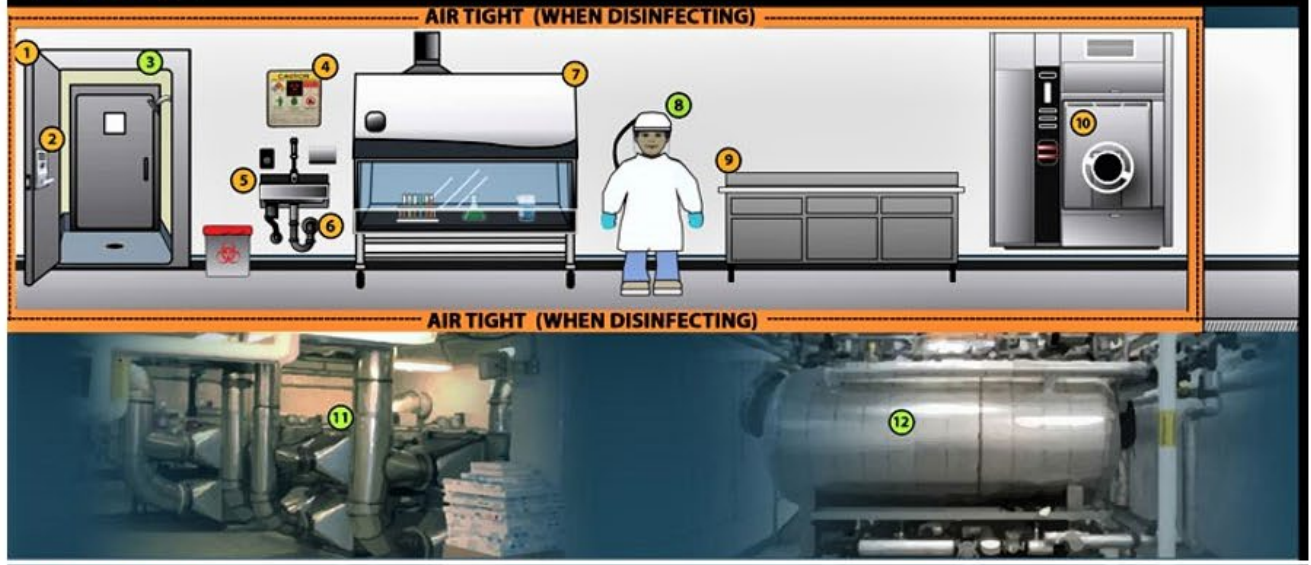

\section{BSL4}

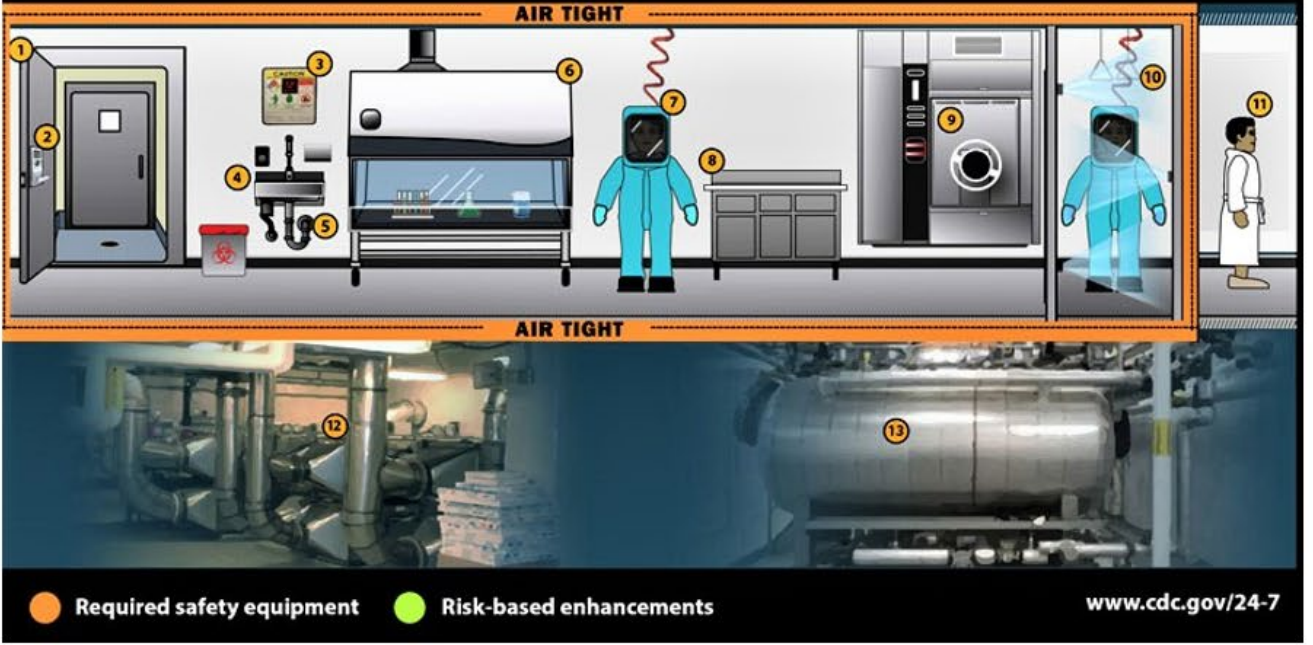

BSL1

1- Controlled Access

2- Hand Washing Sink

3- Sharp Hazards

Warning Policy

4- Personal Protective

Equipment

5- Laboratory Bench

6- Autoclave

\section{BSL2}

1- Controlled Access

2- Hand Washing Sink

3- Sharp Hazards

Warning Policy

4- Physical

Containment Device

5- Personal Protective

Equipment

6- Laboratory Bench

7- Autoclave

\section{BSL3}

1- Self-Closing,

Double-Door Access

2- Controlled Access

3- Personal Shower ou

4- Sharp Hazards

Warning Policy

5- Hand Washing Sink

6- Sealed Penetrations

7- Physical

Containment Device

5- Powered Air

Purifying Respirator

9- Laboratory Bench

10- Autoclave

11- Exhaust HEPA

Filter

12- Effluent

Decontamination

System

\section{BSL4}

1- Self-Closing,

Double-Door Access

2- Controlled Access

3- Sharp Hazards

Warning Policy

4- Hand Washing Sink

5- Sealed Penetrations

6- Physical

Containment Device

7- Positlive Pressure

Protective Sult

8- Laboratory Bench

9- Autoclave

10-Chemical Shower Out

11- Personal Shower

Out

12- Supply And

Exhaust HEPA Filters

13- Effluent

decontamination

system

$$
\text { شكل 9. نماى شماتيك از سطوح جهار كانه ايمنى زيستى و امكانات، تجهيزات و تاسيسات آنها (IV) }
$$


انتخاب هود ايمنى زيستى مناسب براساس ارزيابى ريسك انواع

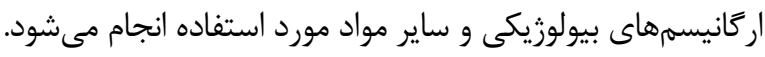

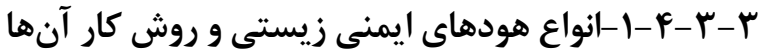

هودهاى ايمنى زيستى بر اساس نيازهاى مختلف مراكز تشخيصى و يزوهشى،ها در سه رد/كلاس ا، باو ب توسعه يافتهاند. هودهاى ايمنى زيستى كلاس ا داراى يك فيلتر بوده كه در قسمت خروجى قرار دارد و فقط از كاربر در برابر مواد شيمايى و

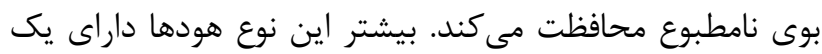

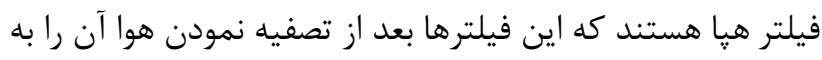

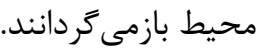

در هودهاى ايمنى زيستى كلاس اهواى اتاق از طريق

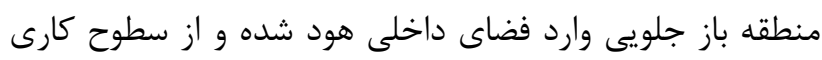

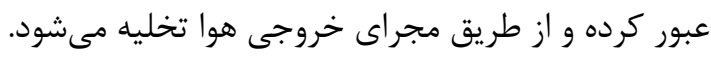

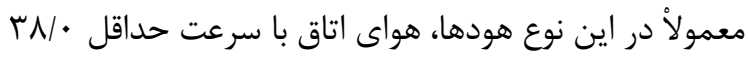

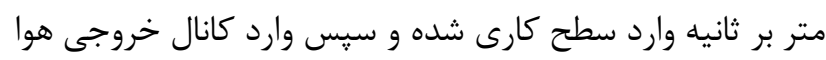
مى

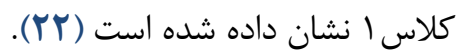

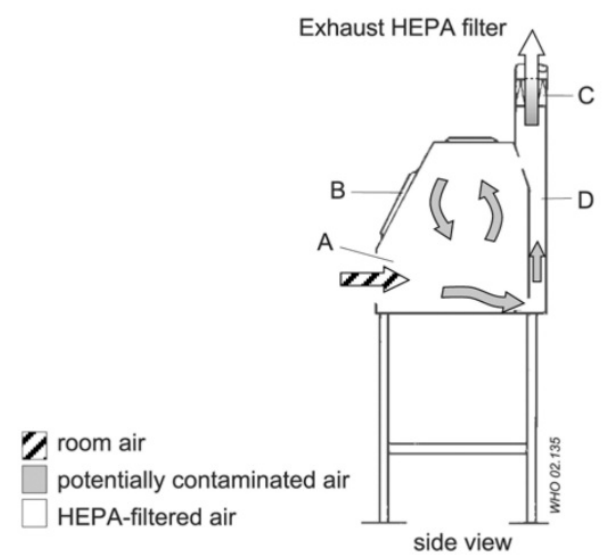

شكل V.نماى شماتيك از كاركرد هود ايمنى زيستى كلاس (IT)

A: Front Opening, B: Sash, C: Exhaust HEPA Filter, D: Exhaust Plenum.

به دليل نياز به كشت سلولى و بافتى براى تكثير ويروسها و

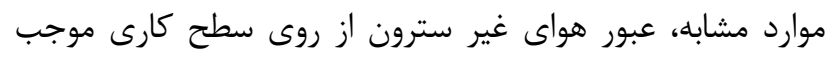

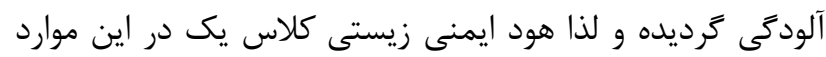

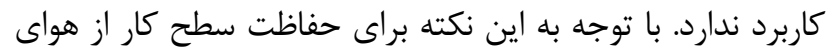

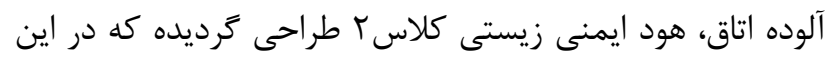

جنانجه اطلاعات دقيق و درستى از قطعه DNA ورودى وجود نداشته باشد بايد در نهايت دقت و احتياط با آنا كآن كار كرد. بلهنوان مثال زمانى كه كتابخانه زنتيكى از زنوم يك اركاني دانيسم

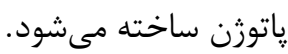

קنانجه محصول زن ورودى سمى است و يا اثرات دارويى و

درمانى دارد بايد احتياطهاى بيشترى در نظر كرفته شود (•r).

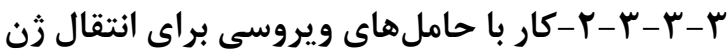

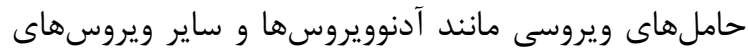

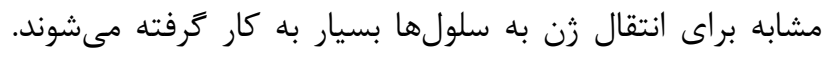

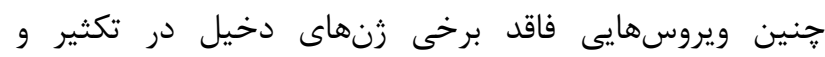
همانندسازى هستند و در سلولهايى كه اين نقص را جبران

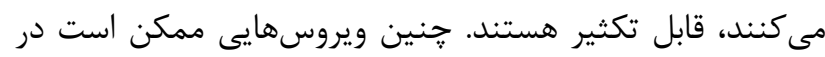

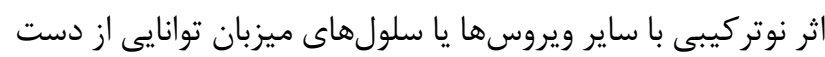

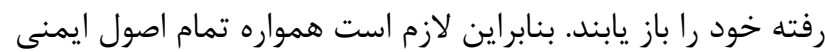
كار با ويروسهاى كامل رعايت شود (Y)

\section{r-Y-Y-Y}

هود ايمنى زيستى (Biologic Safety Cabinet: BSC) يك ركائين فضاى كارى آزمايشكاهى براى كار به صورت ايمن با مواد آلوده يا

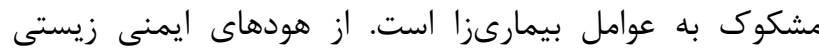

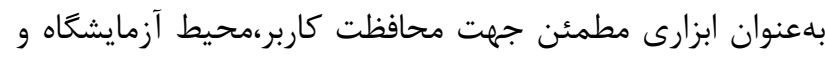
فضاى كار در برابر ذرات معلق در هوا (Aerosol)، ترشحات آلوده

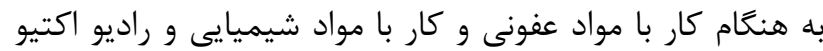
طراحى شدهاند.

معمولا در انواع مختلف هودها (كابينتهاى) ايمنى زيستى از فيلترهاى با بازده بالا در برابر عبور ذرات High Efficiency)

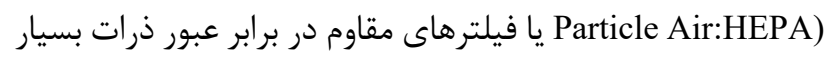
ريز (Ultra Low Particle Air: ULPA) در خروجى سيستم (اكزاست) يا تأمين كننده هوا براى به دام انداختن ذرات معلق در هوا استفاده مىشود. اين فيلترها قادر هستند

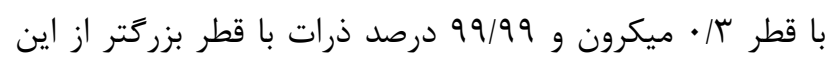

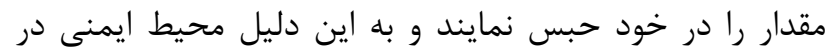

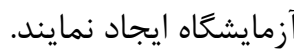

بسته به ساختار اين فيلترها، جهت جريان هوا و ارتفاع ينجره، مىتوان به سطوح مختلفى از محافظت كاركنان، محصول

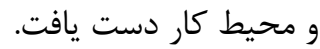


با قابليت جابجايى و جداسازى قطعات است كه در طراحى آزمايشكاه بايد بهطور جدى بله آن توجه شودا

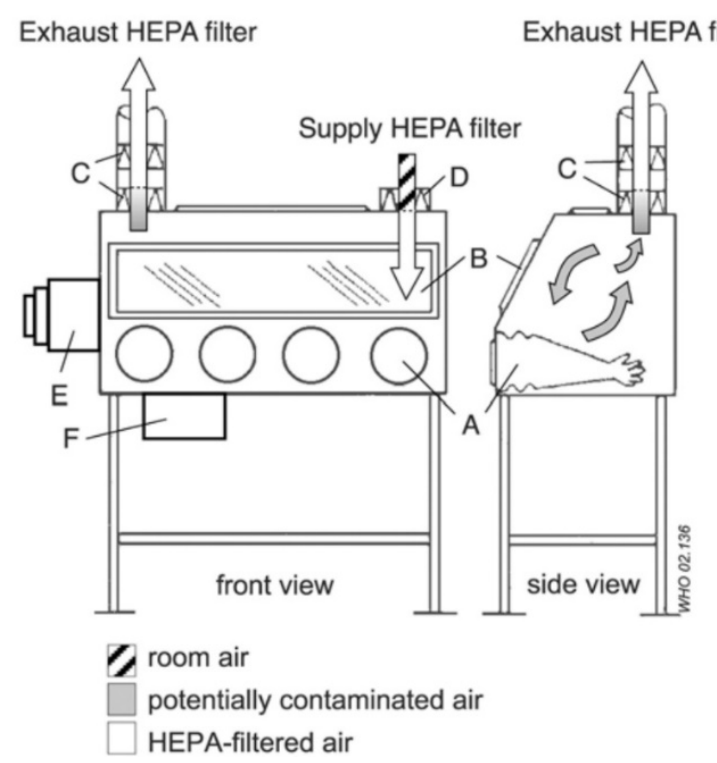

شكل ^. نماى شماتيك از كاركرد هود ايمنى زيستى كلاس ب (M (1)

يكى از مشكلاتى كه خصوصاً در آزمايشكاههاى بيمارستانى

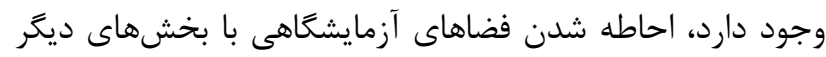

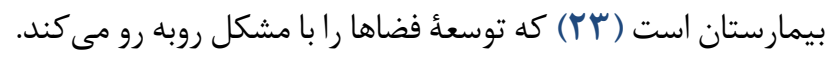

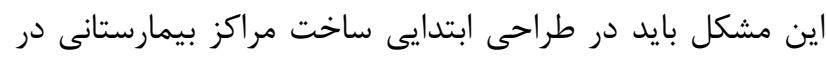

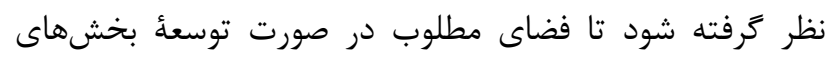

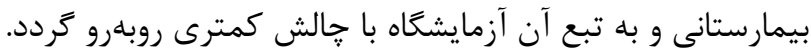

طراحى آزمايشكاههاى يزشكى با درنظر كرفتن مواردى كه در

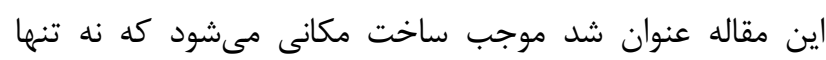

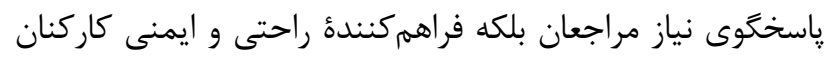

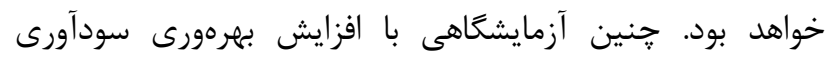

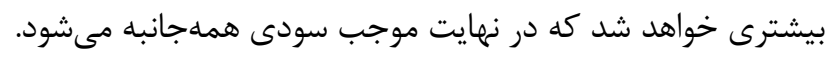

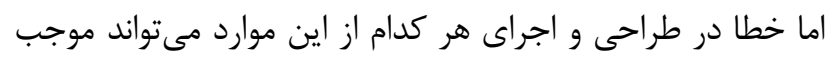

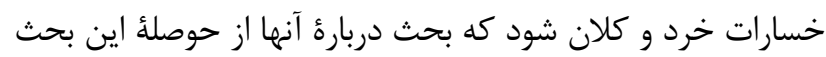

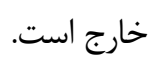

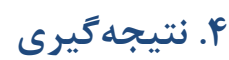

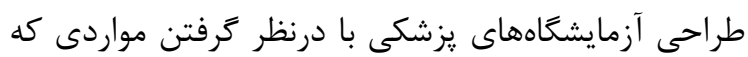

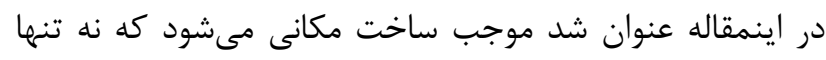

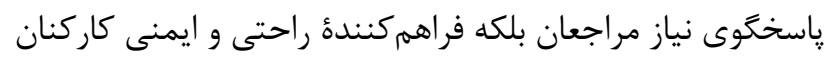

هودها هواى سترون فيلتر شده توسط فيلتر هيا روى سطح كار جريان مىيابد و لذا اين هودها در كشت سلولى و بافتى كاربرد دارند. هود ايمنى زيستى كلاس إمتداولترين نوع هود در

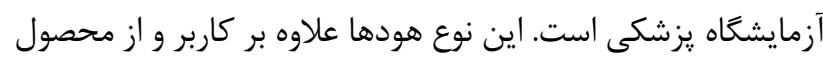

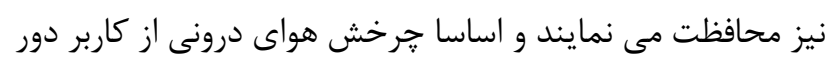

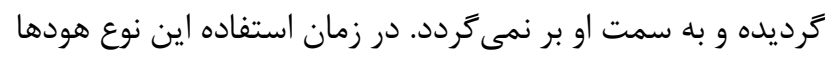

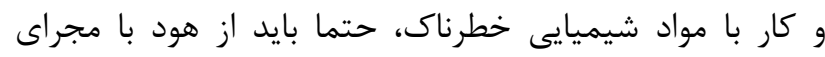

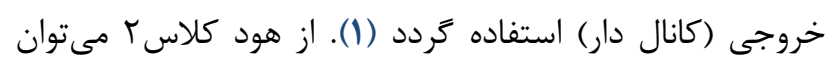

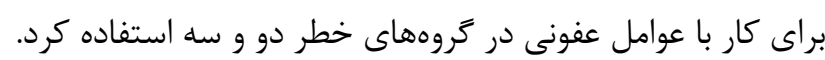
هود كلاس در جهار زير رده (نوع) مختلف بر اساس نياز

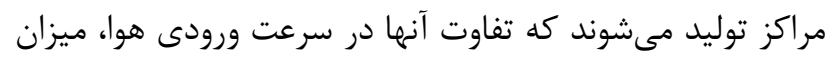
هواى برگشتى به سطح كار و عملكرد سامانه تعيين كننده ميزان

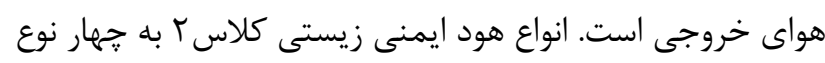

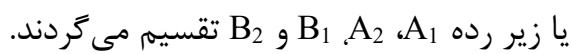

در هودهاى ايمنى زيستى كلاس ب بالاترين سطح محافظت

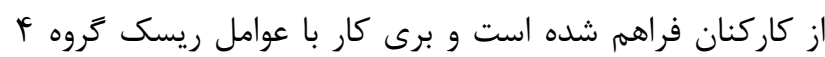

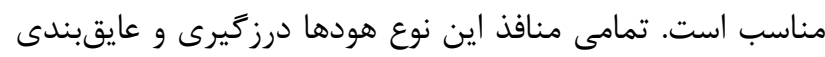

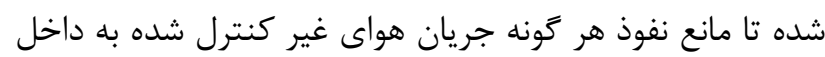

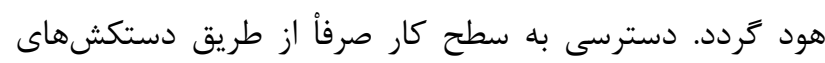

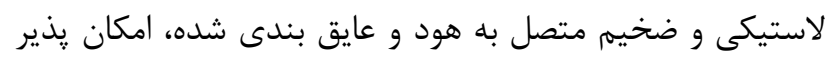

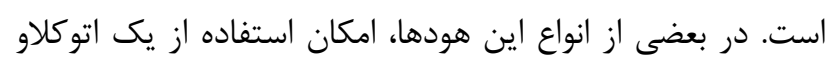

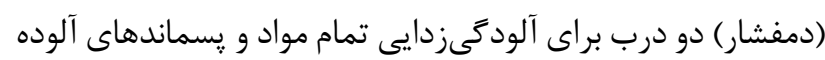

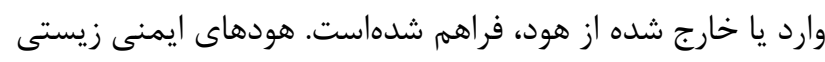

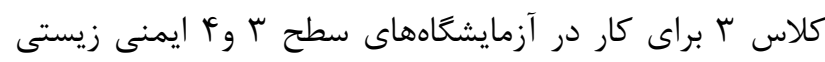

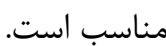
در هودهاى ايمنى زيستى كلاس ب هوا بيرون هود ابتدا از فيلتر هيا عبور كرده و وارد هود ميىشود. سيس إيس كاين هواى تصفيه

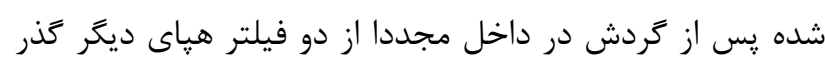
كرده واز هود خارج مىشود (1). در شكل ^ نماى شماتيك از كاركرد هود ايمنى زيستى

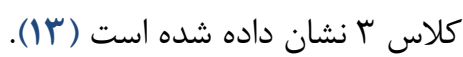

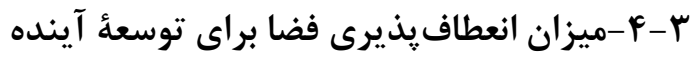

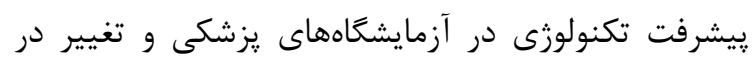
نيازها لزوم ييشبينى تغيير فضاى كاربرى و توسعة آتى در فضاها

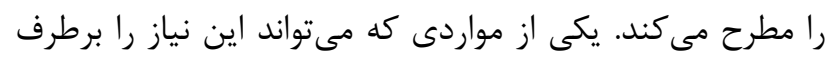

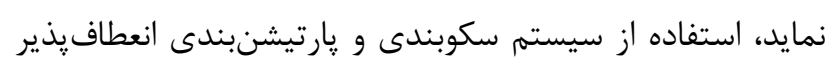




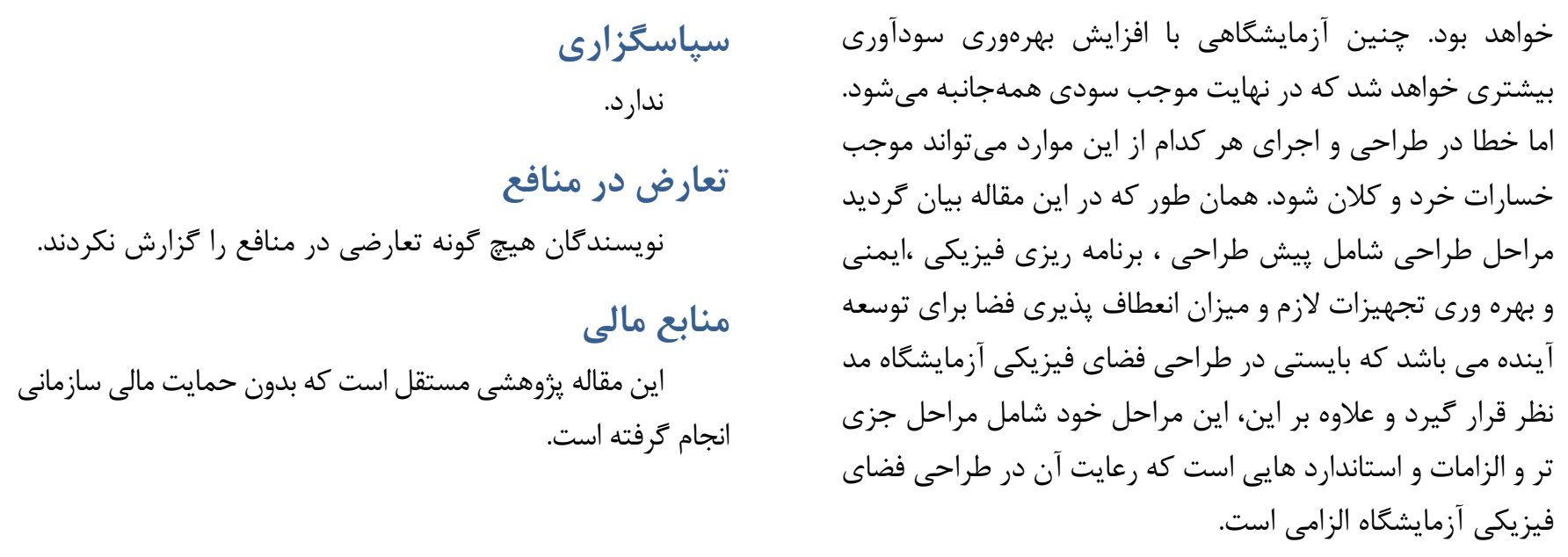

